\title{
Endothelial dysfunction and diabetes: roles of hyperglycemia, impaired insulin signaling and obesity
}

\author{
Wineke Bakker $\cdot$ Etto C. Eringa $\cdot$ Pieter Sipkema . \\ Victor W. M. van Hinsbergh
}

Received: 6 July 2008 / Accepted: 22 August 2008 / Published online: 22 October 2008

(C) The Author(s) 2008. This article is published with open access at Springerlink.com

\begin{abstract}
Endothelial dysfunction comprises a number of functional alterations in the vascular endothelium that are associated with diabetes and cardiovascular disease, including changes in vasoregulation, enhanced generation of reactive oxygen intermediates, inflammatory activation, and altered barrier function. Hyperglycemia is a characteristic feature of type 1 and type 2 diabetes and plays a pivotal role in diabetesassociated microvascular complications. Although hyperglycemia also contributes to the occurrence and progression of macrovascular disease (the major cause of death in type 2 diabetes), other factors such as dyslipidemia, hyperinsulinemia, and adipose-tissue-derived factors play a more dominant role. A mutual interaction between these factors and endothelial dysfunction occurs during the progression of the disease. We pay special attention to the possible involvement of endoplasmic reticulum stress (ER stress) and the role of obesity and adipose-derived adipokines as contributors to endothelial dysfunction in type 2 diabetes. The close interaction of adipocytes of perivascular adipose tissue with arteries and arterioles facilitates the exposure of their endothelial cells to adipokines, particularly if inflammation activates the adipose
\end{abstract}

E.C. Eringa is supported by the Dutch Diabetes Foundation (grant 2003.00.030), the Dutch Kidney foundation (grant C03.2046), and the Dutch organization for scientific research (grant 916.76.179). V.W.M. van Hinsbergh is supported by the European Vascular Genomics Network (grant LSHM-CT-2003-503254).

W. Bakker $(\bowtie) \cdot$ E. C. Eringa $\cdot$ P. Sipkema $\cdot$

V. W. M. van Hinsbergh

Laboratory of Physiology, Institute for Cardiovascular Research,

VU University Medical Center,

Van der Boechorststraat 7 ,

1081BT Amsterdam, The Netherlands

e-mail: w.bakker@vumc.nl tissue, and thus affects vasoregulation and capillary recruitment in skeletal muscle. Hence, an initial dysfunction of endothelial cells underlies metabolic and vascular alterations that contribute to the development of type 2 diabetes.

Keywords Endothelial dysfunction · Diabetes · Obesity · Adipokines $\cdot$ Hyperglycemia

\section{Introduction}

Diabetes mellitus is a common metabolic disease with a high and growing prevalence affecting $4 \%$ of the population and, worldwide, 171 million people in 2000 and an expected 366 million in 2030 (Wild et al. 2004). Type 1 diabetes is characterized by an absolute deficiency of insulin attributable to pancreatic insuffiency. In contrast, type 2 diabetes is characterized mainly by insulin resistance, viz., a reduced response of glucose uptake rate during insulin exposure, and therefore represents a relative deficiency of insulin in spite of high plasma levels of insulin. Because of the progressive dysfunction of the pancreatic $\beta$-cells, this eventually can also lead, in type 2 diabetes, to an absolute deficiency of insulin for tissue cells. Endothelial dysfunction comprises a number of functional alterations in the vascular endothelium, such as impaired vasodilation, angiogenesis and barrier function, inflammatory activation, and increased plasma levels of endothelial products, all of which are generally associated with cardiovascular disease. Endothelial dysfunction in type 1 diabetes is probably the consequence of the metabolic changes related to diabetes, in particular hyperglycemia. With age, a number of microvascular complications develop in type 1 diabetes patients, in particular retinopathy, nephropathy, and the diabetic foot. In contrast, the relationship between 
endothelial dysfunction and diabetes is much more complex in type 2 diabetes and saddles patients with a heavy burden, particularly with respect to cardiovascular disease. In type 2 diabetes, a common cause may underlie both endothelial dysfunction and the development of hyperglycemia, whereas other factors such as dyslipidemia additionally contribute to both. Endothelial dysfunction may thus play a primary role in the development of the vascular complications of type 2 diabetes, complications that are aggravated by hyperglycemia, but that are not primarily dependent on the development of hyperglycemia.

In the present survey, we discuss the nature of endothelial dysfunction in type 1 and 2 diabetes and the way that it relates to these condittions. After discussing the effects of hyperglycemia on endothelial functioning, we will turn to the way that, in type 2 diabetes, obesity and fat-derived adipokines act locally on arteries and arterioles and can contribute to insulin resistance and reduced glucose uptake in muscle. Further insights into the interrelationship between endothelial/vascular (dys)functioning, type 1 and 2 diabetes, and obesity may help to further improve the treatment of these epidemically increasing metabolic disorders.

\section{Normal endothelial functions}

The endothelium of all blood vessels represents a diffuse organ of over $700 \mathrm{~g}$ in the adult man (Wolinsky 1980). Although local differences exist in the endothelium of various types of conduit vessels, resistance vessels, and tissue capillaries, a number of general functions are known that are crucial for the proper functioning of the organism (Aird 2007b; Pober and Sessa 2007; Aird 2007a). In addition, the endothelium of many different organs has specialized functions (Aird 2007b). The endothelium can extend its repertoire of functions by adaptation to various stimuli, including mechanical stress, oxidative and metabolic stresses, inflammation, hypoxia, and many other stresses (Cines et al. 1998; Pober and Sessa 2007).

\section{General functions}

By the nature of its location, the endothelium acts as a blood container, but in addition, it actively regulates the passage of nutrients, hormones, and macromolecules into the surrounding tissue (Cersosimo and DeFronzo 2006). It is covered by a glycocalyx that contributes to the selectivity of its barrier function (van Haaren et al. 2003). Furthermore, the endothelium ensures the fluidity of blood by its contribution to hemostasis. Indeed, living endothelial cells are needed to prevent and limit blood coagulation and the formation of a platelet thrombus and to produce fibrinolysis regulators (van Hinsbergh 2001).
The interaction between flowing blood and endothelium not only involves the interaction of blood constituents and cells with the endothelium, but also includes the sensing of mechanical forces, in particular shear forces that are exerted by the flowing blood on the endothelium. This sensing enables the endothelial cell to respond by acute vasoregulation and by inducing chronic adaptation of the blood vessel. Acute vasoregulation is achieved by the production of vasodilator factors, such as nitric oxide (NO), endotheliumderived hyperpolarization factor (EDHF), and prostaglandins (PGI2/PGE2), of which the relative contribution varies between the different types of vessels (Shimokawa et al. 1996). The endothelium not only responds to vasoactive agents with usually vasodilation, but is also involved in the catabolism, metabolism, and synthesis of various vasoactive agents, particular in the lung (Shaul 1999).

Furthermore, in specific conditions, the endothelium is also able to induce the potent vasoconstrictor endothelin-1 (ET-1). Insulin also acts as a regulator of vasoregulation, as it is able to induce NO and ET-1 release (Schroeder et al. 1999; Cardillo et al. 1999; Ferri et al. 1995). Another important function of the endothelium lies in the regulation of a proper recruitment of leukocytes at sites of inflammation or an immune reaction. Again, both acute responses and chronic adaptation can cause induction of leukocyte adhesion molecules and other gene products. Inflammatory activation of the endothelium can occur, for example, after exposure to bacterial lipopolysaccaride and inflammatory cytokines, of which the potent inducers interleukin-1 (IL-1) and tumor necrosis factor-alpha $(\mathrm{TNF} \alpha)$ have drawn the most attention. Inflammatory activation can also be induced by reactive oxygen intermediates (ROIs), which can be generated by the inflammation process itself and by disturbed metabolic conditions (Gimbrone 1999).

Finally, the endothelium is the major vector in angiogenesis, the formation of new microvessels. This is not only important in development, growth, and tissue repair, but also in capillary perfusion of muscle. Furthermore, in a number of diseases, an improper angiogenesis response causes unwanted growth, risk for local haemorrhage by immature vessels, or insufficient blood supply (Carmeliet 2005).

Endothelial function in glucose metabolism and insulin action

Endothelial cells are metabolically extremely active cells with a high rate of protein synthesis. They can use both glucose and fatty acids as nutrients. Non-esterified fatty acids (NEFA) are liberated from triglyceride-rich lipoproteins by lipoprotein lipase that is bound to the endothelial glycocalyx or are taken up from the plasma. In endothelial cells, the uptake of D-glucose occurs via the Glut-1 glucose 
transporter, which is not influenced by insulin, in contrast to Glut-4 in muscle cells. Therefore, glucose uptake in the endothelial cells reflects the glucose level in the blood independently of insulin sensitivity. However, most of the glucose that reaches the endothelium should not be catabolized, but delivered to the underlying tissue cells.

As the endothelium forms a continuous sealing of the blood, it acts as the gateway for glucose and insulin delivery for tissue cells. Small molecules, such as glucose, can pass through the interendothelial junctions, except for those in the endothelium of brain microvessels, which only allow transcellular receptor GLUT-1-mediated translocation (Pardridge et al. 1990). In principle, Glut-1 may also contribute to the exchange of D-glucose from the blood to the interstitium of other tissues, but its relative contribution has not been systematically investigated and is probably small. This contrasts with the exchange of proteins, such as albumin, which pass endothelial cells transcellularly via the shuttling of caveolar vesicles between the luminal to the abluminal side. These caveolae contain specific receptors facilitating translocation (Simionescu et al. 2002; Schnitzer et al. 1994). The junctions widen and allow paracellular exchange of proteins only under conditions of enhanced demand, e.g., during inflammation, in caveolin-1-deficient animals, which have no functional caveolae, or under hypoxia. Insulin is a small protein $(6,000 \mathrm{Da})$, but nevertheless ample evidence is available that insulinreceptor-mediated binding and exchange determines its exchange from plasma and interstitial fluid (Bottaro et al. 1989; Wiernsperger 1994) and thus its availability to insulin-sensitive tissues, such as muscle, adipose tissue and brain (Fig. 1). Only the liver escapes this control, as it has fenestrated endothelial cells. As a consequence, the endothelium may affect the relative exposure of insulinsensitive tissue cells to insulin after a glucose challenge (Yang et al. 1994; Sjostrand et al. 2002). The delivery of glucose and insulin to a specific tissue depends on the size of the perfused capillary bed (capillary recruitment) and their passage rates over the endothelium. The perfused capillary bed is determined by the pre-existing capillaries and in particular by the vasoregulation of the proximal resistance vessels. Insulin affects this regulation and, thus, glucose and insulin delivery.

Insulin can dilate arteries and arterioles by a receptordependent stimulation of a pathway that involves IRS-1, PI3 kinase, Akt/PKB and endothelial NO synthase (eNOS) and leads to the generation of the potent vasodilator NO (Fig. 1). In addition, insulin is also able to cause rapid release of ET-1, which occurs via a pathway that involves activation of MEK, ERK1/2, and endothelin-converting enzyme. Both effects occur via activation of the insulin receptor, which subsequently phosphorylates insulin receptor substrates (IRS); IRS-1 and IRS-2 have been demonstrated in endothelial cells (Kubota et al. 2003; Montagnani et al. 2002). Deficiency of IRS-1 impairs NO induction by insulin (Montagnani et al. 2002). However, the roles of IRS-1 and IRS-2 in endothelial cells and the balance of their expressions in various metabolic conditions are not completely understood. By analogy with (diabetic) heart cells (Laviola et al. 2001), the interaction of the activated

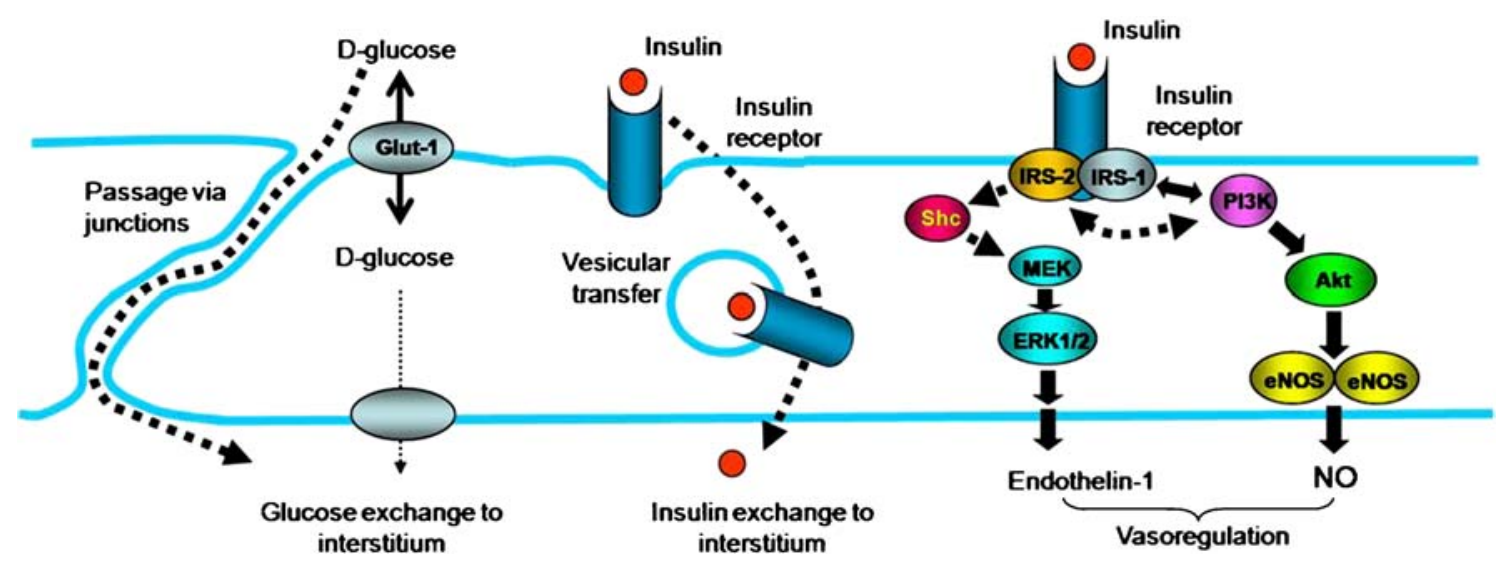

Fig. 1 Delivery of insulin and D-glucose and acute insulin signaling in endothelial cells. Uptake of D-glucose occurs via the glucose transporter Glut-1, which, in contrast to Glut-4 in muscle, is not affected by insulin signaling. Exchange of glucose from the plasma to the interstitial fluid proceeds mainly via intercellular gaps/junctions. In contrast, insulin is shuttled over the endothelium via caveolae after binding to its receptor. In addition, insulin receptor signaling affects vasoregulation by endothelial cells. It has a rapid effect on the release of endothelin-1 and nitric oxide $(N O)$. Activation of the insulin receptor phosphorylates insulin receptor substrates (IRS), of which
IRS-1 and IRS-2 occur in endothelial cells. PI3 kinase complexes with the phosphorylated IRS-1, after which PKB/Akt and subsequently endothelial NO synthase $(e N O S)$ are activated by phosphorylations. The eNOS dimer generates NO. Activation of the insulin receptor also causes activation of MEK-1 and ERK1/2 and subsequently the activation and release of endothelin-1. By analogy with heart cells (Laviola et al. 2001), the interaction of the activated IRS-2 with the adapter protein She might cause phosphorylation of MEK and the subsequent activation steps 
IRS-2 with the adapter protein Shc has been suggested to cause phosphorylation of MEK and the subsequent activation steps. In addition to acute regulation, gene expression is affected. Mice with a vascular endothelial cell-specific insulin receptor deficiency show normal growth and glucose metabolism but display a reduction in ET-1 and eNOS mRNAs (Vicent et al. 2003).

\section{Endothelial dysfunction and diabetes}

\section{Endothelial dysfunction}

The functioning of the endothelium is flexible and adapts to various types of metabolic, mechanical, and inflammatory stress (Cines et al. 1998; Pober and Sessa 2007). However, when this functioning becomes inadequate, e.g., loss of $\mathrm{NO}$ generation, or exaggerated, e.g., improper inflammatory activation, one speaks of endothelial dysfunction. From a mechanistic point of view, as many endothelial dysfunctions exist as endothelial functions. They include changes in barrier function and hemostasis, reduced vasodilator responses, improper inflammatory activation, and angiogenesis (Table 1).

In the clinical context, endothelial dysfunction is regarded as an important and early factor in the pathogenesis of atherothrombosis (Gimbrone 1999; Ross 1999) and vascular complications of diabetes (Stehouwer et al. 1997) and is associated with a number of traditional risk factors including hypercholesterolemia, smoking, hypertension, diabetes mellitus, and insulin resistance and, more recently, obesity (Brook et al. 2001). In this context, it is often thought to represent a collection of simultaneously occurring alterations in endothelial functioning that take place early in arterial disease and that are causal to subsequent changes in the structure and function of the affected blood vessels. However, although an accumulation of ROIs, loss of NO bioavailability, and inflammatory activation of the endothelium play a role in most clinical conditions including diabetes (see below), the exact nature and degree of endothelial dysfunction can vary with the nature of the noxious stimulus and the type of vessel involved.

Endothelial dysfunction and vascular complications of diabetes

Endothelial dysfunctions that are associated with the occurrence and severity of vascular complications in diabetes are summarized in Table 1. Some of them are mainly associated with hyperglycemia and microangiopathy, whereas others are induced by more complex metabolic alterations in type 2 diabetes and particularly contribute to macroangiopathy. After a consideration of various aspects of endothelial dysfunction in diabetes in general, we shall discuss, in the subsequent chapters, the way that hyperglycemia and factors associated with insulin resistance and obesity contribute to these aspects of type 1 and 2 diabetes.

Structural changes in endothelial extracellular matrix and barrier dysfunction

The endothelial cell is polarized and has, as extracellular matrix, a glycocalyx at its luminal side and a basement membrane at its abluminal side. In diabetes, the basement membrane is thickened and altered in composition, because of the enhanced synthesis of matrix proteins by transforming growth factor beta (TGF- $\beta$ ) activity and possibly by inadequate counter regulation of matrix protein synthesis by the defective matrix itself (Chen et al. 2001; Wolf et al. 2005). Chondroitin sulfate proteoglycans and dermatan sulfate proteoglycans are increased at the expense of
Table 1 Endothelial dysfunctions associated with the occurrence and severity of vascular complications in diabetes

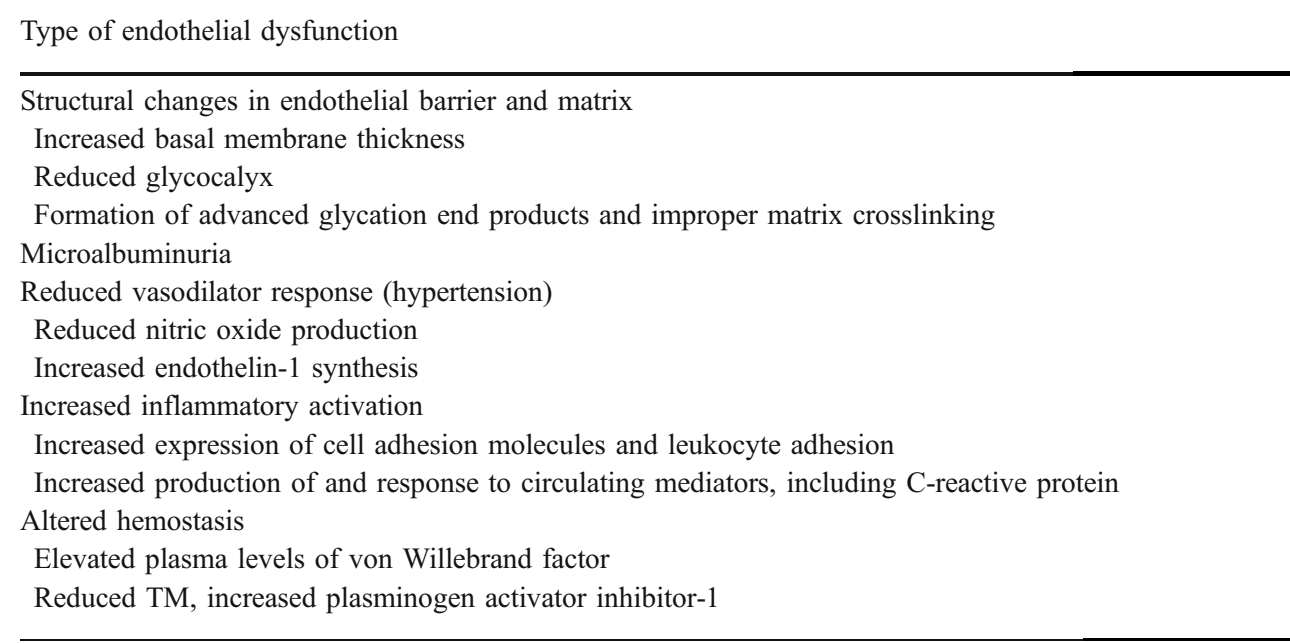


heparan sulfate proteoglycans, which are markedly reduced in diabetes (Heickendorff et al. 1994). At the same time, the thickness of the glycocalyx, which contains large amounts of heparan sulfate proteoglycans, is markedly reduced (Nieuwdorp et al. 2006a, 2006b). Loss of the glycocalyx leads to a wide spectrum of vascular abnormalities, which include the adhesion of mononuclear cells and platelets to the endothelial surface, attenuated NO availability, and is thought to cause a moderately increased leakage of macromolecules through the endothelium of many vessels in hyperglycemia and diabetes (Berg et al. 2006). This phenomenon might be the basis of the Steno Hypothesis (Deckert et al. 1989), which proposes that microalbuminuria (see below) in diabetes reflects a systemic leakage of albumin and atherogenic lipoproteins over the endothelium, thus reflecting an enhanced risk for atherothrombosis and cardiovascular disease. Although this hypothesis may explain the more general localization of atherosclerosis in diabetes as compared with the more focused lesions in hypercholesterolemia (Jensen et al. 1995), several studies have been unable to demonstrate such association between the transcapillary leakage of albumin and microalbuminuria (Nosadini et al. 2005). This indicates that other additional factors determine the functioning of the endothelial barrier toward macromolecules in microalbuminuric patients.

In vitro and animal studies have indicated hyperglycemia as an etiological factor of endothelial barrier injury, with microvascular hyperpermeability and plasma leakage as a consequence (Yuan et al. 2007; Simionescu 2007). Hyperglycemia can stimulate crosslinking and modification of matrix proteins by glyco-oxidation, and advanced glycation end products (AGEs), which are generated in this process, have been reported to alter the synthesis of matrix proteins in animal experiments (Naka et al. 2004). The role of hyperinsulinemia as a contributor to capillary leakage is still controversial (Yuan et al. 2007). Several studies have suggested that the exchange of insulin in muscle capillaries is retarded; this could be attributable either to reduced permeability or to reduced perfusion of the muscle capillary bed (Castillo et al. 1994; Sjostrand et al. 2002).

\section{Microalbuminuria}

Microalbuminuria, which is defined in humans as $30-300 \mathrm{mg}$ urinary albumin excretion per 24 h (Mogensen 1984; American Diabetes Association 2005), is generally considered as an indicator of early kidney damage and atherosclerosis in diabetes (Stehouwer and Smulders 2006; Weir 2007). Its origin is still incompletely understood. In the Steno Hypothesis (Deckert et al. 1989), leakage of albumin into the urine is a reflection of widespread vascular damage and thus predicts cardiovascular disease. Indeed, epidemiological and prospective studies have shown that microalbuminuria is predictive for cardiovascular disease in particular in patients with diabetes and hypertension, but also in the general population, independently of other classical risk markers (Weir 2007).

Stehouwer et al. (1997) have suggested that the close linkage between microalbuminuria and endothelial dysfunction in type 1 and 2 diabetes patients might explain the finding that microalbuminuria is a risk marker for atherosclerotic cardiovascular disease. The type of endothelial dysfunction appears to be important in this aspect. In type 2 diabetes patients, these authors have found that microalbuminuria, endothelial dysfunction as estimated from plasma von Willebrand factor (vWF) levels, and low-grade inflammation, although tightly linked, are independently associated with risk for cardiovascular death (Stehouwer et al. 2002). In constrast, in elderly individuals without and with diabetes, microalbuminuria is linearly associated with impaired endothelium-dependent flow-mediated vasodilation, supporting the concept that reduced endothelial NO synthesis plays a role in the association of microalbuminuria with cardiovascular disease risk (Stehouwer et al. 2004). Other investigators have proposed that individual variation in vascular function is simultaneously associated with a variable excretion of micro amounts of albumin and susceptibility to developing cardiovascular disease subsequently (de Zeeuw et al. 2006).

Both changes in the hydrostatic pressure and the permselectivity of the glomeruli are thought to contribute to microalbuminuria. One might anticipate that changes in the local availability of growth factors, such as vascular endothelial growth factor (VEGF) and TGF $\beta$, or unfavorable conditions, e.g., hyperglycemia, may affect the interaction between the podocyte foot ends and the glomerular endothelium and thus alter glomerular permselectivity, together with changes in the glomerular proteoglycans (Wolf et al. 2005). In addition to increased glomerular leakage of albumin, decreased protein resorption in the renal tubuli will also contribute to the appearance of albumin in the urine (D'Amico and Bazzi 2003).

$\mathrm{NO}$ availability and dysfunctional vasoregulation

A key feature of endothelial dysfunction is the inability of arteries and arterioles to dilate appropriately in response to stimuli. This limits the delivery of nutrients and hormones to the distal tissues. Two mechanisms play an important role. Dominant is a decreased bioavailability of the vasodilator NO. In addition, increased synthesis of ET-1 by activated endothelial cells induces vasoconstriction. The bioavailability of $\mathrm{NO}$ is determined by a balance of $\mathrm{NO}$ production by eNOS (also called NOS-III) and reduction of active NO by quenching of NO by ROIs, particularly the 
superoxide anion (Williams et al. 2002). The NO generation occurs in a tightly coupled sequence of reactions at the eNOS dimer, which is stabilized by $\mathrm{BH} 4$ and requires several cofactors (Raman et al. 1998). Uncoupling of eNOS causes the enzyme to produce superoxide rather than NO (Schmidt et al. 1996; Wever et al. 1997).

Superoxide and other ROIs inhibit NO bioavailability in several ways. First, superoxide reacts directly with NO and forms peroxynitrite. Peroxinitrite is a potential damaging agent and contributes by itself to eNOS uncoupling, thus aggravating reduced NO production. Second, ROIs reduce the availability of tetrahydrobiopterin (BH4), a cofactor required for NO synthesis from eNOS. Loss of structural interaction of $\mathrm{BH} 4$ with eNOS results in eNOS uncoupling and the production of superoxide instead of NO by eNOS (Raman et al. 1998; Hodnett and Hester 2007). Infusion of BH4 partially counteracts the reduced acetylcholineinduced vasodilation in type 2 diabetes patients, supporting the concept that eNOS uncoupling and reduced NO bioavailability contribute to endothelial dysfunction in diabetes (Heitzer et al. 2000). A third mechanism by which ROI reduce NO availability is by inhibition of the enzyme dimethylarginine dimethylaminohydrolase (DDAH; Lin et al. 2002). As DDAH converts the endogenous eNOS inhibitor called asymmetric dimethylarginine (ADMA), the inhibition of DDAH causes the accumulation of ADMA and the suppression of NO production (Lin et al. 2002). Elevated plasma ADMA levels are a risk marker for cardiovascular events and diabetic kidney disease in patients with type 1 and type 2 diabetes (Lajer et al. 2008; Krzyzanowska et al. 2007). Intensive treatement of type 2 diabetes patients reduces, amongst others, both ADMA levels and cardiovascular risk (Yasuda et al. 2006).

In addition to ROIs, an increase in arginase is another mechanism leading to NO availability. Arginase metabolizes L-arginine to urea and ornithine. As enhanced arginase activity can decrease tissue and cellular arginine levels, L-arginine availability to eNOS is reduced (Berkowitz et al. 2003), which leads to decreased NO production and increased superoxide generation (Kaesemeyer et al. 2000). Recently, increased arginase activity in diabetes has been reported to contribute to vascular endothelial dysfunction by reduced L-arginine availability to NO synthase (Romero et al. 2008). A possible mechanism involved is the activation of RhoA by high glucose levels, thereby increasing arginase activity, which in turn initiates a feed-forward cycle of diminished NO levels and further oxidative stress (Romero et al. 2008). Insulin suppresses the expression of genes from the urea synthesis pathway, including arginase. As insulin signaling is disturbed in diabetes, a diabetes-induced increase in arginase activity might explain the decreased L-arginine levels reported in plasma from diabetic animals and patients (Pieper et al.
1997; Hagenfeldt et al. 1989) and in vascular tissue of diabetic rats (Pieper et al. 1997).

Insulin resistance and oxidative stress, such as that induced by hyperglycemia, can both contribute to an increased production of the potent vasoconstrictor ET-1. As will be discussed below, the balance between NO- and ET-1-dependent pathways plays a major role in vasoregulation by insulin and the dysfunction of vasoregulation in diabetes and obesity.

Other vasodilating factors such as endothelium-derived hyperpolarization factor (EDHF) may also be altered in diabetic animals (De Vriese et al. 2000). The contribution of EDHF is most pronounced in smaller vessels, which limits a possible role for EDHF in diabetic endothelial dysfunction to the smaller resistance arteries and arterioles. Within the limited number of studies available, various effects of diabetes on EDHF production (reduction, compensatory increase, no contribution) have been reported depending on the type of vessel studied and experimental setting (De Vriese et al. 2000; Fitzgerald et al. 2007).

\section{Leukocyte adhesion and inflammation}

The generation of ROIs also affects other functions of the endothelium. Either directly via ROI or via a reduction of $\mathrm{NO}$, the nuclear factor kappa-B (NF-kB) pathway is activated with, subsequently, the activation of numerous genes involved in inflammation (Tesfamariam and DeFelice 2007; Cines et al. 1998; Pober and Sessa 2007). In particular, the cell adhesion molecules VCAM, ICAM-1, and E-selectin have drawn much attention. As they represent major receptors controlling the influx of monocytes and other inflammatory cells into the arterial wall, their expression is considered as a hallmark in the etiology of atherosclerosis (Gimbrone 1999). Their importance is further underlined by the observation that the proper arterial shear forces exerted by the flowing blood on the endothelium have anti-atherogenic properties by reducing the inflammatory activation of and expression of these leukocyte adhesion molecules by the endothelium (Dekker et al. 2005; Gimbrone 1999; SenBanerjee et al. 2004). Many studies in experimental animals have shown increased expression of leukocyte adhesion molecules and low-grade inflammation of the endothelium in diabetes and their effects on the development and aggravation of atherosclerotic lesions. In humans, the moderate elevation of Creactive protein (CRP) in atherosclerosis, insulin resistance, and diabetes has been interpreted as being the consequence of a systemic low-grade inflammation of the arteries (Jager et al. 1999; Ridker 2007; Schalkwijk et al. 1999; Yudkin et al. 1999). Furthermore, an increase of soluble forms of VCAM-1 and ICAM-1 has been observed in diabetes patients and is associated with an increase risk of 
developing cardiovascular disease (Jager et al. 2000; Becker et al. 2002).

AGEs have been reported to be able to activate NF-KB in endothelial cells via the activation of the receptor RAGE. This has been found in studies in vitro and in experimental animals (Naka et al. 2004; Yan et al. 1994). AGE/RAGEmediated activation of reduced nicotinamide-adenine-dinucleotide phosphate (NADPH) oxidase has also been reported (Wautier et al. 2001). Further studies have shown that RAGE has additional ligands with a much higher affinity, such as S100 protein, which are also involved in inflammation, and that other vascular cells, e.g., macrophages also contain RAGE (Yan et al. 2008). Hui et al. (2001) have pointed out that radical generation by AGEs can be caused by the ability of AGEs to bind ROIgenerating heavy metals. This may explain the considerable variation that exists in reports of the effect of AGEs on endothelial cells (Wautier et al. 2001; Yan et al. 2008; Lieuw-a-Fa et al. 2006).

Hyperinsulinemia accelerates atherosclerosis by directly enhancing neutrophil transendothelial migration through increasing endothelial PECAM-1 expression via mitogenactivated protein kinase activation (Okouchi et al. 2002).

\section{Decreased thromboresistance}

Several proteins involved in hemostasis have been evaluated as potential risk indicators of cardiovascular disease in diabetes (Alessi and Juhan-Vague 2008). An increase in soluble thrombomodulin may point to a decreased ability to activate the anticoagulant protein $\mathrm{C}$ pathway, whereas a decrease in tissue-type plasminogen activator and an increase of its inhibitor PAI-1 may point to reduced fibrinolysis (Stehouwer et al. 1997, 2004). Of particular interest is vWF, which is both involved in the adhesion of platelets to collagen and in complexes with coagulation factor VIII. Increases in plasma $\mathrm{vWF}$ concentrations have consistently been associated with an increased risk of cardiovascular complications and death in diabetes patients (Stehouwer et al. 1991, 2004). The way that $\mathrm{vWF}$ contributes to this risk is still uncertain.

\section{Altered angiogenesis and tissue repair}

The regeneration function of endothelial cells as represented by angiogenesis is dysfunctional in hyperglycemia and diabetes. Diabetes patients have poor wound healing, impaired collateral formation after vascular occlusion or myocardial infarction, and an increased risk of rejection of transplanted organs (Martin et al. 2003). Reduced vascularization probably also contributes to diabetic neuropathy. In contrast, an excessive neovasularization is observed in the eyes of patients with diabetic retinopathy (Aiello 2005).
Although this may appear surprising, one has to realize that the cause of this excessive neovascularization is improper vascularization of the retina itself. Indeed, narrower retinal arteriolar caliber before the onset of neovascularisation predicts the development of diabetes, providing further evidence that microvascular changes may contribute to the pathogenesis of diabetes (Nguyen et al. 2008). Because of the reduced blood supply, an additional layer of unstable vessels grows in the vitreous fluid over the retina, thereby increasing the risk for vascular leakage and bleeding into the eye. In patients with proliferative diabetic retinopathy, huge levels of VEGF have been found in the eye fluid, indicating an important contribution of this angiogenic factor (Aiello et al. 1994). Furthermore, the level of VEGF is lower in diabetes patients treated with angiotensinconverting enzyme (ACE) inhibitors suggesting that angiotensin 2 also contributes (Hogeboom et al. 2002). Either diabetes itself or the hypoxia that results from endothelial and vascular injury may induce these factors. Hyperglycemia is a major determinant of vessel damage in diabetic retinopathy with ROI, accumulation of glycolysis intermediates, and AGEs as potential mediators. Reduction of the accumulation of glycolysis intermediates and blockage of AGE formation has been shown to be effective in an animal setting (Hammes et al. 2003; Tamarat et al. 2003). Anti-VEGF antibodies have been demonstrated to be efficacious in counteracting neovascularization in adult macular degeneration in the eye and are being evaluated in patients with diabetic retinopathy (Andreoli and Miller 2007). Finally, hyperinsulinemia and overactivation of insulin and insulin-like growth factor-1 receptors in the retinal microcirculation have been shown, in rodents, to contribute to VEGF expression and retinopathy associated with diabetes.

In addition to VEGF, VEGF receptors can also be affected in diabetes. Chronic coronary heart disease in diabetic patients is accompanied by increased VEGF myocardial expression and a decreased expression of its receptors together with a down-regulation of its signal transduction. The last-mentioned might be partially responsible for the reduced neoangiogenesis in diabetic patients with ischemic cardiomyopathy (Sasso et al. 2005). Furthermore, the neurotrophin $\mathrm{p} 75$ receptor, which is upregulated in the ischemic hindlimbs of diabetic mice induces endothelial apoptosis and has angiogenic properties (Caporali et al. 2008).

\section{Hyperglycemia-related endothelial dysfunction in type 1 diabetes}

Hyperglycemia is a feature of both type 1 and type 2 diabetes. Ample evidence exists that intensified regulation of blood glucose markedly reduces the development and progression of microvascular complications (United 
Kingdom Prospective Diabetes Study [UKPDS] 1995; The Diabetes Control and Complications Trial Research Group 1993). The UKPDS and subsequent studies have shown that the efficacy of tight glucose control is less pronounced for macrovascular complications, particularly atherosclerosis and its sequels, in type 2 diabetes patients (Stratton et al. 2000), and very stringent control could even aggravate the disease (The Action to Control Cardiovascular Risk in Diabetes Study Group 2008; The ADVANCE Collaborative Group 2008). This indicates that determinants other than hyperglycemia also play a dominant role in the development of macrovascular disease. Notwithstanding this, hyperglycemia is still considered not only to be pivotal in diabetes-associated microvascular complications, but also to contribute to worsening macrovascular complications.

Endothelial activation by hyperglycemia

Major vascular defects in diabetes, in which hyperglycemia plays an important role, include increased arterial stiffness and reduced NO production in resistance arteries and arterioles, reduced glomerular function and microalbuminuria in the kidney, and inappropriate neovascularization in the eye (Stehouwer et al. 1997). In nearly all of these cases, the hyperglycemic state is thought to affect endothelial functioning. A number of biochemical mechanisms has been observed, which Michael Brownlee has unified in one mechanism (Brownlee 2001, 2005). According to this mechanism (Fig. 2), the production of reactive oxygen radicals generated in particular by mitochondrial uncoupling and the subsequent activation of poly(ADP-ribose) polymerase (PARP) and the inhibition of the glycolysis enzyme D-glyceraldehyde-3-phosphate dehydrogenase (GAPDH) cause accumulation of glycolysis pathway intermediates, which activate at least four biochemical pathways known to be altered in endothelial cells by hyperglycemia: protein kinase C (PKC) activation, generation of methylglyoxal and AGEs, activation of the hexosamine pathway, and reduction of the NADPH/NADP+ ratio by activation of the sorbitol pathway.

The accumulation of glycolysis-derived triose-phosphates can activate PKC by their conversion to DAG, a known activator of PKCs. In particular, the isoforms PKC- $\beta 2$ and $\mathrm{PKC} \delta$ have received much attention, on the one hand because they increase the expression of genes that are enhanced in diabetes, such as PAI-1, ET-1, VEGF, and TGF- $\beta$, and on the other hand, because of the efficacy of PKC- $\beta 2$ blockers in reducing diabetic microangiopathy in animals (Koya and King 1998; Noh and King 2007). However, the efficacy of these blockers in man is still unclear.

Furthermore, the accumulated glycolysis-derived triosephosphates can be converted into methylglyoxal, which can modify proteins intracellularly, forming AGEs within the cell. Methylglyoxal modification of heat-shock protein Hsp27 (Schalkwijk et al. 2006) and mSin3A, which enhances angiopoietin-2 transcription (Yao et al. 2007), have been reported in endothelial cells. An increase in cellular methylglyoxal has also been found to arrest cell growth, to induce apoptosis (Okado et al. 1996; Thornalley 1990), and to stimulate the endocytosis of macromolecules (Shinohara et al. 1998). Intracellular methylglyoxal is degraded by glyoxylase. Overexpression of glyoxylase I
Fig. 2 Role of hyperglycemia on endothelial activation. The production of reactive oxygen radicals following mitochondrial uncoupling and the subsequent activation of poly(ADP-ribose) polymerase $(P A R P)$ and inhibition of the glycolysis enzyme D-glyceraldehyde-3-phosphate dehydrogenase $(G A P D H)$ result in accumulation of glycolysis pathway intermediates. These activate at least four biochemical pathways known to be altered in endothelial cells by hyperglycemia (top right)

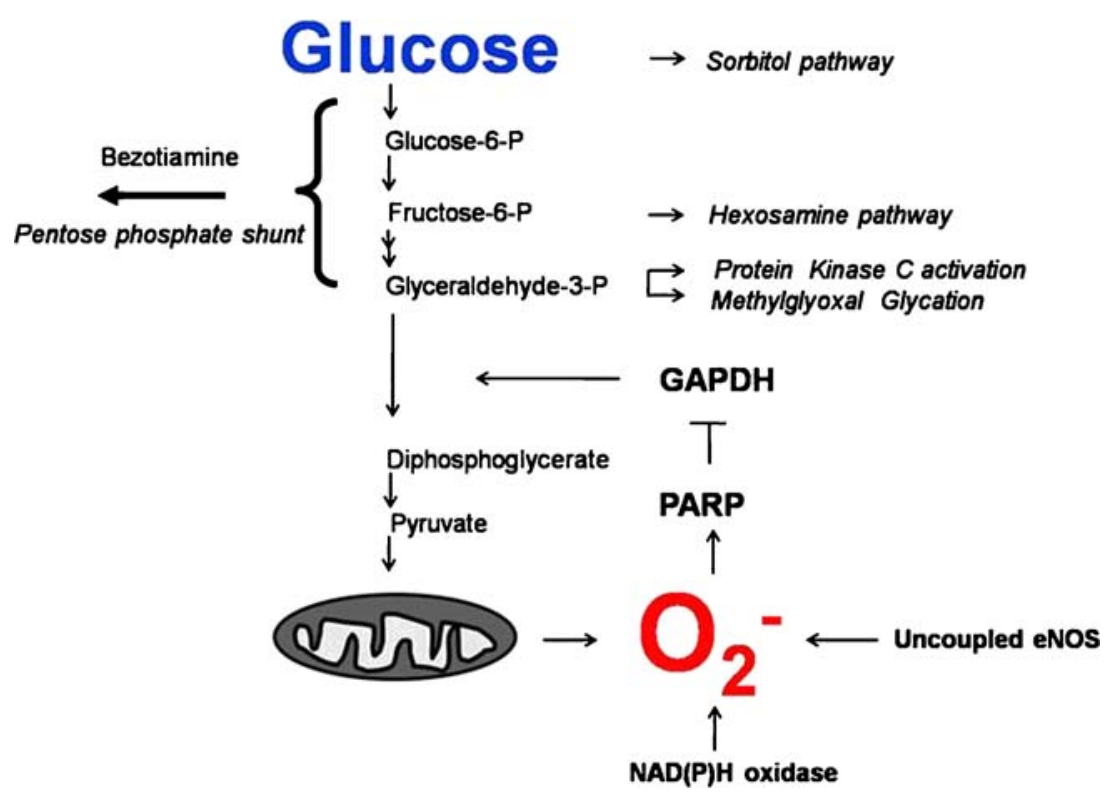


in endothelial cells results in a decrease of the intracellular hyperglycemia-induced methylglyoxal concentration accompanied by normalization of endocytosis (Shinohara et al. 1998). High glucose levels also cause the formation of extracellular AGEs. As discussed above, such AGEs may induce inflammatory activation of endothelial cells (Yan et al. 1994).

The ambient glucose concentration regulates the cellular concentration of uridine 5'diphosphate $\mathrm{N}$-acetylglucosamine (UDP-GlcNAc), which is generated from the glycolysis intermediate fructose-6-phosphate by glutamine: fructose-6-phosphate aminotransferase in the hexosamine pathway (Hart et al. 2007; Sayeski and Kudlow 1996). UDP-Glc is a precursor for proteoglycans and O-linked GlcNAc (O-GlcNAc) addition to nuclear and cytoplasmic proteins (Hart et al. 2007). Increased O-glycosylation of SP-1 causes increased activity of this transcription factor and a subsequent elevated gene transcription of PAI- 1 and TGF- $\beta$ (Du et al. 2000). Furthermore, an increased flux of glucose through the hexosamine pathway has been associated with insulin resistance associated with defects in Akt activation in 3 T3 L1 adipocytes (Vosseller et al. 2002) and insulin resistance in skeletal muscle (Marshall et al. 1991; Patti et al. 1999).

The sorbitol pathway is also stimulated by hyperglycemia and can contribute to hyperglycemic complications in animals. However, its significance for endothelial dysfunction has been disputed as aldolase inhibitors have little effect in man and the sorbitol pathway is poorly active in endothelial cells (King 1996).

Brownlee's unifying mechanism for the pathobiology of hyperglycemia-induced diabetic complications (Brownlee 2005) thus proposes that hyperglycemia induces the generation of superoxide, which subsequently results, via the activation of PARP, in the inhibition of GAPDH and the accumulation of glycolysis intermediates. Subsequent animal studies have demonstrated that the application of benfotiamine, which lowers the levels of glycolysis intermediates by stimulation of the pentose phosphate shunt, has a beneficial effect on endothelial survival and microvascular function in the eye of rodents (Hammes et al. 2003). Additional evidence for the importance of this mechanism has been provided by studies that interfere with superoxide production in diabetic mice, a procedure that corrects defective ischemia-induced neovascularization (Ceradini et al. 2008). In the original model, the uncoupling of mitochondria is considered to be a major source of superoxide generation. However, it should be kept in mind that, in addition to uncoupled mitochondria, several other mechanisms could generate ROIs. In particular, the activation of NADPH oxidases has been reported as an important contributor to ROI stress (Dworakowski et al. 2008; Munzel et al. 2008), whereas the uncoupling of eNOS also contributes to the generation of superoxide (Wever et al. 1997).

\section{Pseudohypoxia}

To explain various changes in hyperglycemia-exposed endothelial cells, such as enhanced TGF- $\beta$ expression and collagen synthesis, Williamson et al. (1993) postulate that pseudohypoxia occurs in endothelial cells. In support of this concept, the transcription factor HIF-1 $\alpha$ is increased when angiotensin II stimulates endothelial cells in the presence of high glucose concentrations (Williams et al. 1995). Superoxide and glycosylation probably do not affect HIF- $1 \alpha$ itself, but rather enzymes that regulate its stability, in particular proline hydoxylases (Ratcliffe 2006). Such mechanisms may result in the enhanced production of important factors in diabetes, such as VEGF and TGF- $\beta$.

\section{Hyperglycemic memory}

A common feature of all above-mentioned pathways is their reversible nature, once hyperglycemia is corrected. However, the progression of microvascular complications once euglycemia is re-established in dogs has led to the hypothesis that the mechanisms associated with hyperglycemia have an irreversible nature causing the persistence of vascular damage involving the so-called hyperglycemic memory (Engerman and Kern 1987; Roy et al. 1990). This phenomenon has been confirmed in man (King 1996; Fioretto et al. 1998). Two mechanisms have been hypothesized to explain this phenomenon. First, the generation of irreversible advanced AGEs, the products of non-enzymatic glycation of proteins and nucleotides. In addition to their aforementioned effects, AGE-mediated cross-linking of collagens contributes to long-lasting arterial stiffness. As the visco-elastic artery dampens the pressure wave that is transferred to the periphery after every heart beat, arterial stiffness increases the force with which this pulse arrives in the microvessels of the extremities, with potential damaging effects in, for example, small resistance vessels in the legs. Second, enduring effects of oxidative stress induced by hyperglycemia have been proposed to induce enduring inflammatory activation (Dworakowski et al. 2008; Munzel et al. 2008; Rask-Madsen and King 2007). Recently, Forbes et al. (2008) have suggested that oxidative stress might also affect the methylation of specific proteins and thus contribute to hyperglycemic memory.

Taken together, hyperglycemia causes the activation of endothelial cells by various pathways resulting in endothelial dysfunction and vascular disease, in particular microangiopathy and arterial stiffness. Normalization of glucose levels is necessary to counteract these effects, but hyperglycemic 
memory causes a delay in the effectiveness of this treatment in reducing various dysfunctions and complications.

\section{Endothelial dysfunction in type 2 diabetes}

Type 2 diabetes can be characterized by insensitivity to insulin-mediated glucose uptake, which in combination with impaired beta cell function increases circulating blood glucose. Blood vessels of patients with type 2 diabetes (Okon et al. 2005) and diabetic mice (Okon et al. 2003; Bagi et al. 2003) show attenuated endothelium-dependent vasodilation, which is caused by attenuation of NO production and decreased NO sensitivity of the smooth muscle cells, enhanced breakdown of NO by reactive oxygen species, decreased Akt phosphorylation, and enhanced vasoconstrictor tone (Okon et al. 2005). Although the precise origins of endothelial dysfunction in type 2 diabetes remain unclear, several studies have suggested that endothelial and vascular dysfunction initiates well before the occurrence of overt hyperglycemia. Impairment of endothelium-dependent vasodilation has been reported in first-degree relatives of type 2 diabetes subjects (Caballero et al. 1999; Goldfine et al. 2006) and subjects with impaired glucose tolerance (Caballero et al. 1999).

\section{Dyslipidemia}

In addition to hyperglycemia, dyslipidemia and chronic inflammatory activation of adipose tissue and the arterial wall are hallmarks of type-2 diabetes and its vascular complications (Mazzone et al. 2008). Triglyceride-rich lipoproteins are usually elevated in diabetes and contribute to increased levels of NEFA in the circulation. Remnants of triglyceride-rich lipoproteins can affect endothelial cells directly via the activation of the receptor LOX-1, by which they stimulate $\mathrm{NAD}(\mathrm{P}) \mathrm{H}$ oxidase-dependent superoxide formation and induce cytokine release and apoptosis in endothelial cells in vitro (Shin et al. 2004). NEFA also can activate endothelial cells (see below). Furthermore, triglyceride-rich lipoproteins and their remnants, together with (oxidized) cholesterol-delivering low density lipoproteins (LDL), can activate endothelial cells indirectly as they contribute to lipid accumulation in macrophages and subsequently the production of inflammatory cytokines and oxidized products (Kume et al. 1992; Vora et al. 1997; Saraswathi and Hasty 2006). LDL oxidation can occur within the oxidative milieu of an inflamed vessel wall, after which oxidized products can damage or activate vascular cells and induce the expression of leukocyte adhesion molecules on the endothelium (Vora et al. 1997; Cybulsky and Gimbrone 1991). As type 2 diabetes patients have smaller LDL particles, their passage through the arterial endothelium will be increased, whereby they can contribute more to cholesterol delivery into the arterial wall. This accumulation is aggravated by a reduction in cholesterolremoving HDL particles, which is generally observed in the plasma of type 2 diabetes patients. In addition to effects on the arterial wall, the altered circulating lipids in type 2 diabetes contribute to lipid loading and inflammatory activation of adipose tissue and the production of adipokines with subsequent vascular effects, as further explained below (see Fig. 3).

Genetic predisposition for the development of type 2 diabetes

The "thrifty gene" theory of Neel (1962) suggests genetic selection for the storage of nutrients, which, with regard to today's Western lifestyle, predisposes to the development of obesity and diabetes. Studies of ob/ob mice with obesity caused by leptin deficiency and of $\mathrm{db} / \mathrm{db}$ mice with type 2 diabetes and obesity attributable to a defective leptin receptor support this hypothesis. Heterozygous animals, $\mathrm{ob} /+$ and $\mathrm{db} /+$, survive longer during fasting (Coleman 1979). Mutations in the leptin receptor in humans have been described to be associated with the development of obesity (Clement et al. 1998) and to be expressed in the vasculature (Bouloumie et al. 1998). Leptin-deficient ob/ob mice have impaired endothelial dysfunction, which is restored after leptin administration through a mechanism in which leptin enhances NO release from the endothelium (Winters et al. 2000). Db/db mice (Pannirselvam et al. 2002) and fa/fa zucker rats (Eringa et al. 2007), both with defective leptin receptors, also show endothelial dysfunction. Furthermore, the fa/fa rats exhibit selective resistance to insulin signaling and, in particular, a selective resistance to the activation of PI3 kinase, which normally is involved in NO production (Jiang et al. 1999). These data indicate that comparable mechanisms are involved in endothelial dysfunction in type 2 diabetes and obesity.

Other interesting candidates in the genetic predisposition of endothelial function in type 2 diabetes are proteins from the insulin signaling pathway, e.g., insulin receptor substrates (IRS) and eNOS but also newly discovered proteins present in the vascular endothelium such as PKC $\theta$ and PPAR $\gamma$ (131-134). Polymorphisms in IRS proteins are associated with insulin resistance (Sesti et al. 2001) and disrupted IRS phosphorylation in endothelial cells leading to decreased NO production (Kim et al. 2005a). However, the exact role of IRS in endothelial dysfunction in the microvasculature is not completely clear. PKC $\theta$ has recently been discovered in the vascular endothelium of mice and humans and is involved in disturbed insulinmediated vasoreactivity induced by fatty acids (Bakker et al. 2008). PKC $\theta$ knock-out mice are protected from acute 


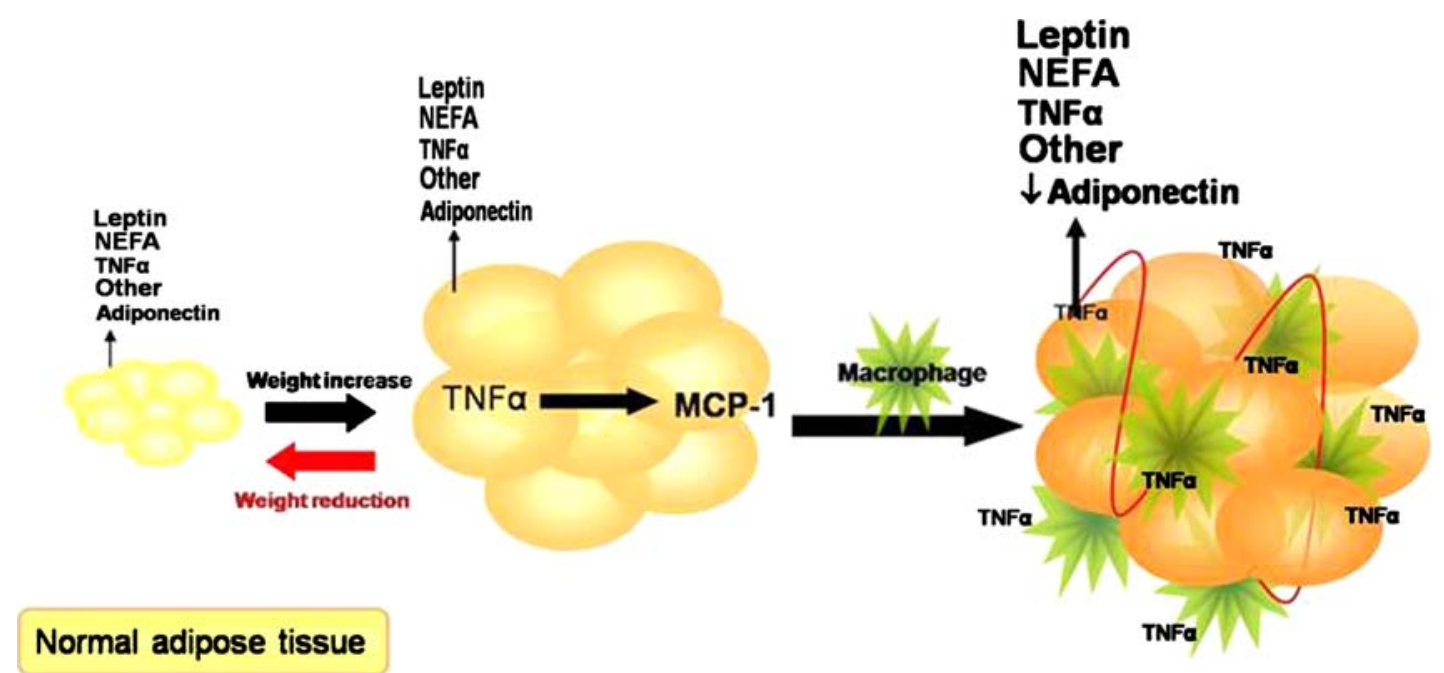

Increasing adipocyte size

Adipose tissue with macrophages

Fig. 3 Inflammation of adipose tissue and altered secretion of adipokines. Inflammation in adipose tissue is probably initiated by the secretion of low amounts of tumor necrosis factor-alpha $(T N F \alpha)$, as a consequence of, for example, changes in membrane cholesterol because of the increased size of the adipocytes. TNF $\alpha$ is able to regulate the secretion of other adipokines by stimulating pre-

fatty-acid-induced insulin resistance (Kim et al. 2004), and an overactive PKC $\theta$ gene could be involved in endothelial dysfunction in type 2 diabetes. PPAR $\gamma$ is mostly known for regulating adipogenesis and lipid metabolism (Kliewer et al. 2001) but has also been described to be present and active in vascular endothelium (Marx et al. 1999). Interference with PPAR $\gamma$ signaling produces endothelial dysfunction via a mechanism involving oxidative stress and causes vascular hypertrophy and inward remodeling (Beyer et al. 2008). The observation of the regulation of insulin signaling by NEFA and PKC $\theta$ additionally suggests a relationship between fatty-acid-induced activation of PKC $\theta$ and endothelial dysfunction in obesity and diabetes.

Impaired insulin signaling and ER stress

Insulin resistance and reduced insulin signaling are associated with endothelial dysfunction. Defective insulin signaling causes inadequate production of NO and ET-1. In the resting pre-prandial state, the vasodilator and vasoconstrictor effects of insulin are in balance, and insulin adapts this balance to the demands of the the body to produce either more NO, causing vasodilation, or more ET-1, causing vasoconstriction. However, in obese states, the balance of vasodilation and vasoconstriction is shifted toward vasoconstriction. In obese rats, these signaling pathways are differently affected: insulin-mediated activation of the Akt and NO pathway is reduced, but insulin-mediated activa- adipocytes to produce MCP-1 and then the recruitment of macrophages (Xu et al. 2003; Wellen and Hotamisligil 2003). Subsequently, TNF $\alpha$ creates a hierarchy of cytokines within adipose tissue (Coppack 2001; Trayhurn and Wood 2004) and will change the excretion profile of adipose tissue into a pro-inflammatory state (represented by the increased letter size of the indicated adipokines)

tion of ERK1/2 and ET-1 is intact (Jiang et al. 1999). Accordingly, we have recently found that insulin induces ET-1-dependent vasoconstriction in skeletal muscle arterioles of obese rats (Eringa et al. 2007). Experimental studies in healthy rats have demonstrated that ET-1 infusion in vivo severely blunts the increased capillary recruitment and limb blood flow caused by insulin (Ross et al. 2007).

The manner in which insulin signaling becomes impaired in the vascular endothelium is still poorly understood. In type 2 diabetes, endoplasmic reticulum stress (ER stress) may represent a plausible link between insulin resistance and endothelial dysfunction.

In non-endothelial cells (liver, adipose tissue, pancreas) and intact mice, a so-called unfolded protein stress or ER stress has been reported to be involved in disturbed insulin signaling (Ozcan et al. 2004). Increases in protein synthesis, enhanced generation of ROIs, and other aspects of metabolic stress can cause ER stress, which evokes a series of reactions that result in changes in the translation of proteins, activation of JNK (Jun kinase) and IKK (IKB kinase), and induction of new, often inflammation-related genes (for reviews, see Eizirik et al. 2008; Zhang and Kaufman 2008). This results simultaneously in a reduction of IRS-1-mediated insulin signaling and a state of lowdegree inflammatory activation (Fig. 4; Ozcan et al. 2004, 2006), suggesting not only the potential role of ER stress as a link between obesity, insulin resistance, and diabetes, but 
also that, in mice, a reduction of ER stress by chemical chaperones might restore glucose homeostasis in type 2 diabetes. Endothelial cells have a high protein synthesis capacity, are maximally exposed to elevations of nutrients in the blood, contain all the key proteins involved in ER stress (Luo et al. 2008), and have been shown indeed to display ER stress after exposure to oxidized phospholipids (Gharavi et al. 2007) or homocysteine (Austin et al. 2004). Therefore, ER stress probably contributes to the reduced NO availability and increased expression of leukocyte adhesion molecules that accompany endothelial dysfunction.

Moreover, Eringa et al. (2006) have shown that JNK can be activated by TNF $\alpha$ in the endothelium of skeletal muscle arterioles of rat and causes a reduced vasodilatory response to insulin. JNK is thought to be able to phosphorylate serine-residues on IRS-1 and therewith to reduce the ability of insulin to phosphorylate tyrosine residues on IRS-1, all of which becomes manifest as insulin resistance (Hotamisligil 2005; Taniguchi et al. 2006). As a consequence, insulinmediated AKT activation and NO production are impaired. As $\mathrm{TNF} \alpha$ can induce ER stress in other cells (Xue et al. 2005), TNF $\alpha$-induced activation of JNK in endothelial cells may also involve activation of the ER stress signaling pathway. Figure 4 shows a simplified scheme of the way that ER stress can affect endothelial cells, comparable to other cell types. The precise role of ER stress in endothelial dysfunction in type 2 diabetes is a challenging new field that needs to be further examined.

The involvement of ER stress may be complex. The uncoupling of eNOS and subsequent generation of peroxynitrite and exposure to inflammatory mediators, such as $\mathrm{TNF} \alpha$, can cause ER stress (Xue et al. 2005; Dickhout et al. 2005). However, ER stress may also facilitate eNOS impairment and TNF $\alpha$ generation. Therefore, a mutual interaction probably exists between factors that cause ER stress and factors that are generated by ER stress. This can produce a type of cell activation that is self-perpetuating and therefore difficult to normalize. In particular, the growth and displacement of adipose tissue and adipokines derived thereof can markedly enhance endothelial activation and dysfunction.

Obesity and endothelial dysfunction

Obesity is an independent risk factor for coronary ( $\mathrm{Al}$ Suwaidi et al. 2001) and systemic (Brook et al. 2001) endothelial dysfunction, which are detectable before the onset of diabetes (Galili et al. 2007). Impaired vasodilator responses at the level of the resistance vessels of the nutritive capillary beds develops progressively, together with an increase in adiposity (de Jongh et al. 2006; Perticone et al. 2001; Serne et al. 1999). The close association between measures of adiposity and microvascular function suggests communicative pathways between adipose tissue and the microvasculature. Obesity, in particular visceral obesity, is strongly associated with insulin resistance (Reaven 1995). Therefore, the presence of endothelial dysfunction in obese subjects or animal models might be related to the insulin-resistant state. However, a possible role of obesity in inducing endothelial dysfunction before the development of and independent of insulin resistance has been suggested in a rat model of diet-induced obesity (Erdei et al. 2006). We have recently hypothesized that perivascular fat has an important effect on endothelial vasoregulation in diabetes and obesity. To clarify the effect of perivascular fat on endothelial function and vasoregulation, we shall briefly survey inflammation and adipokine production by adipose tissue.

\section{Obesity and inflammation}

Changes in the regulation of nutrient metabolism in obesity promote nutrient storage in adipose tissue (Schoeller and Buchholz 2005). This change in nutrient metabolism, rather than steady-state glucose and insulin concentrations, causes a pro-inflammatory state in adipose tissue. Adipose tissue

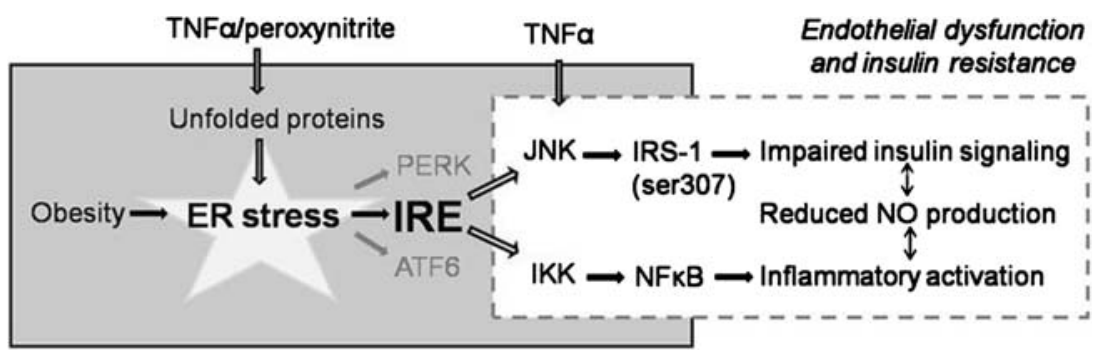

Fig. 4 Representation of ER stress inducing endothelial dysfunction in type 2 diabetes. In various cells, the accumulation of unfolded proteins in the endoplasmic reticulum (ER stress) can activate the proteins inositolrequiring $1 \alpha(I R E)$, double-stranded RNA-dependent protein kinase (PKR)-like ER kinase (PERK), and activating transcription factor 6 (ATF6) in the ER membrane and cause diverse effects resulting in altered gene induction, protein translation, and cell signaling. Activated by ER stress, IRE starts to phosphorylate Jun kinase (JNK), which induces disturbed insulin signaling in endothelial cells by inhibiting IRS1 by phosphorylation at ser307, and IKB kinase (IKK), which leads to activation of $\mathrm{NF} K \mathrm{~B}$ and inflammatory activation. This causes a reduced NO production by endothelial cells 
exhibits distinct secretory profiles that depend on adipose tissue mass. The secretion of a number of bioactive molecules, such as NEFAs, TNF $\alpha$, IL-6, angiotensinogen (Harte et al. 2003a; Rahmouni et al. 2004), and plasminogen activator inhibitor type 1 (Harte et al. 2003b; Shimomura et al. 1996), is significantly increased in adipose tissue from obese animals and humans. In contrast, the production of adiponectin, a hormone that increases fatty acid oxidation and inhibits hepatic glucose production, is diminished (Arita et al. 1999; Combs et al. 2002). Of note, weight loss as a result of lifestyle changes is associated with a reduction in the plasma levels of inflammatory markers, such as IL-6, IL-18, and C-reactive protein, and with an increase in the circulating concentration of adiponectin (Esposito et al. 2003). These observations strongly support the notion that the production of adipose-derived signals is regulated at least partly by the adipose tissue mass.

Inflammation in adipose tissue, as observed in obesity, is characterized by an increased size and number of fat cells and predicts the number of macrophages in adipose tissue (Xu et al. 2003; Weisberg et al. 2003). In obesity, 50\% of adipose tissue consists of macrophages and the size of the fat cells is approximately $120 \mu \mathrm{m}$, compared with values of $5 \%-10 \%$ macrophages and a fat cell size of $70 \mu \mathrm{m}$ in the adipose tissue of lean mice (Hauner 2004; Weisberg et al. 2003). Inflammation in adipose tissue is probably initiated by the secretion of low amounts of $\mathrm{TNF} \alpha$, which stimulate pre-adipocytes to produce MCP-1 resulting in the recruitment of macrophages (Xu et al. 2003; Wellen and Hotamisligil 2003) and a changed excretion profile (Fig. 3).

\section{Adipokines}

Adipose tissue secretes a variety of adipokines, such as fatty acids, $\mathrm{TNF} \alpha$, leptin, adiponectin, and probably many more, that modulate vascular tone, nutritive blood flow, and insulin sensitivity. These adipokines alter smooth muscle contractility, both directly and indirectly, by interacting with endothelium-dependent vasodilation.

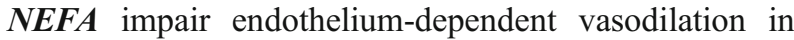
conduit arteries (Lundman et al. 2001; Davda et al. 1995) and in the microcirculation (de Jongh et al. 2004), insulinmediated capillary recruitment, and glucose uptake in humans and rats (Clerk et al. 2002; de Jongh et al. 2004). Insulin-mediated nutritive blood flow is blunted by lipid infusion, and this effect correlates well with the inhibition of insulin-mediated muscle glucose uptake (Clerk et al. 2002). Whereas data from isolated rabbit femoral arteries suggest that NEFA directly decrease eNOS activity (Davda et al. 1995), evidence from aortic endothelial cells has shown that NEFA also inhibit the insulin-mediated activation of Akt and eNOS (Kim et al. 2005b). Indeed, we have recently found, in muscle resistance arteries, that the fatty acid, palmitic acid, induces insulin-mediated vasoconstriction of muscle resistance arteries at concentrations observed in obesity, through the inhibition of the insulin-mediated activation of Akt and eNOS. PKC $\theta$ plays an important role in this interaction (Bakker et al. 2008). This study suggests a direct interaction between free fatty acids (FFA) and insulin in the muscle microcirculation, leading to vasoconstriction of muscle resistance arteries. We propose that NEFA shift the balance of insulin's vasoactive effects toward insulin-mediated vasoconstriction in skeletal muscle arterioles (Fig. 5), thereby causing a reduction in blood flow and capillary perfusion, which results in decreased glucose delivery and uptake in muscle.

$\boldsymbol{T N F} \boldsymbol{\alpha}$ release by adipose tissue is increased in obesity (Hotamisligil et al. 1993). Based on animal and in vitro data, TNF $\alpha$ has been proposed to reduce all of the following: endothelial NO production, insulin-stimulated glucose uptake in skeletal muscle, capillary recruitment (Youd et al. 2000), insulin-mediated vasodilation in muscle resistance arteries (Eringa et al. 2006), and NO production in aortic endothelial cells (Kim et al. 2001; Li et al. 2007). Several proteins have been shown to mediate the interaction between TNF $\alpha$ and insulin, such as p38 mitogen-activated protein kinase (Li et al. 2007), JNK (Eringa et al. 2006), and IKK (Kim et al. 2001). A new source of TNF $\alpha$ that has recently been identified is perivascular adipose around coronary arteries (Mazurek et al. 2003). This implies that TNF $\alpha$ is produced by tissue directly adjacent to the vascular wall and may mean that circulating levels of

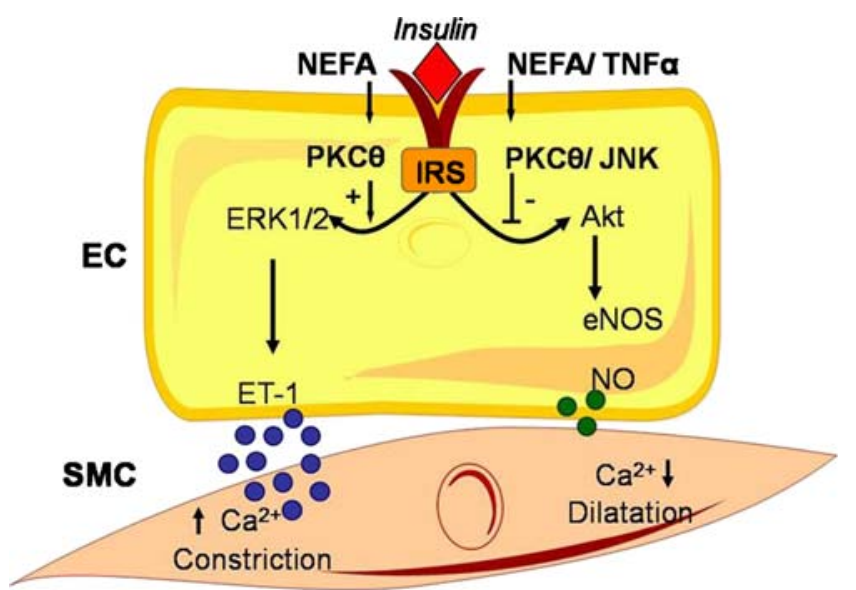

Fig. 5 Effect on insulin signaling by TNF $\alpha$ or non-esterified fatty acids (NEFA). Normal insulin signaling is mediated by either insulin receptor substrate (IRS), Akt, eNOS, and NO production leading to vasodilation or by ERK1/2 and ET-1 production leading to vasoconstriction. TNF $\alpha$ and NEFA affect the insulin signaling pathway by the activation of $\mathrm{JNK}$ or $\mathrm{PKC} \theta$, leading to impaired Akt activation induced by TNF $\alpha$ and NEFA, and increase in ERK1/2 activation by NEFA, both of which lead to insulin-mediated vasoconstriction in muscle resistance arteries 
$\mathrm{TNF} \alpha$, which remain low in obesity (Hotamisligil et al. 1995), underestimate the biologically relevant concentrations of this cytokine.

Leptin was the first endocrine product of adipose tissue to be identified (Zhang et al. 2005) and has recently been found to regulate vascular function through local (Nakagawa et al. 2002; Vecchione et al. 2003) and central (Aizawa-Abe et al. 2000) mechanisms. Leptin is a vasodilator in coronary arteries (Minokoshi et al. 2002) and in human forearm resistance arteries (Nakagawa et al. 2002) through endothelium-dependent (Sierra-Honigmann et al. 1998) and endothelium-independent mechanisms (Nakagawa et al. 2002). A direct interaction between leptin and insulin has been shown in aortic endothelium. Leptin and insulin, in a synergistic mechanism, have been shown to enhance NO production by the phosphorylation of eNOS at Ser1177 (Vecchione et al. 2003). In contrast to these vasodilator effects, leptin also increases sympathetic nerve activity (Aizawa-Abe et al. 2000; Rahmouni et al. 2005) and enhances ET-1 release from vascular endothelium (Quehenberger et al. 2002). Paradoxically, circulating leptin levels are elevated in obesity, apparently contradicting the beneficial effects of leptin described above. To explain this, recent studies have demonstrated the impairment of leptin's metabolic effects and leptin-induced NO production, i.e. "leptin resistance", in obesity (Beltowski et al. 2003; Rahmouni et al. 2005) and human hypertension (Tsuda and Nishio 2004). Leptin resistance may be caused by inflammatory mechanisms, as CRP impairs intracellular leptin signaling (Correia et al. 2002; Chen et al. 2006). Therefore, resistance to the vasodilator effects of leptin may contribute to vascular dysfunction in obesity.

Adiponectin has recently emerged as an adiposetissue-derived modulator of endothelial function. Adiponectin increases NO production in vascular endothelium by increasing the Ser 1177 phosphorylation of eNOS (Chen et al. 2003; Hattori et al. 2003), inhibits endothelial cell activation (Chen et al. 2003; Kobashi et al. 2005; Ouchi et al. 1999), and associates negatively with risk of a cardiovascular event (Hotta et al. 2000). In obesity, adiponectin levels are decreased (Arita et al. 1999), contributing to reduced vascular function (Pilz et al. 2005). In the coronary circulation, adiponectin produced by epicardial adipose tissue regulates the cardiac flow reserve (Date et al. 2006).

\section{Local versus systemic adipokine secretion}

Obesity-related consequences, such as insulin resistance and endothelial dysfunction, are dependent on the location of fat accumulation. For example, abdominal adipose tissue contains more monocytes and macrophages than subcutaneous depots. Morphological studies have revealed substantial differences between non-obese subcutaneous and intra-abdom- inal fat depots. Macrophages have been found in direct contact with mature adipocytes in abdominal adipose tissue (Bornstein et al. 2000). Moreover, adipose tissue from obese mice exhibits adipocytes with an increased size and clusters of small nucleated cells, compared with non-obese mice. These small nucleated cells form giant cells by fusion of multiple macrophages; this is also observed in instances of chronic inflammation (Xu et al. 2003). Furthermore, waist to hip ratio, a measure of abdominal fat accumulation, is correlated with cardiovascular disease and inflammatory factors, such as TNF $\alpha$ (Seidell et al. 2001; Hotamisligil et al. 1995). Population studies have suggested that an increased waistto-hip ratio may reflect a relative abundance of abdominal fat (increased waist circumference) and peripheral muscle atrophy (decreased hip circumference; Seidell et al. 1997). The abundance of abdominal adipose tissue is associated with macrophage infiltration and cytokine production (Bornstein et al. 2000). The peripheral muscle atrophy is associated with a low glucose uptake in muscle and a decrease in insulin clearance (Seidell et al. 1997).

Local adipokine secretion causes a local high concentration of inflammatory products; this is often miscalculated because of an inability to measure locally produced factors but can predict inflammation by systemic inflammation markers. However, increasing fat pads around insulinresponsive organs such as the vasculature, skeletal muscle, and cardiac tissue cause local high concentrations of adipokines, which may have huge effects on insulin signaling. Perivascular adipose tissue (PAT) is present around all conduit arteries and in some microvascular beds, such as that of the mesentery (Verlohren et al. 2004). We have observed that PAT around skeletal muscle arterioles is increased in a diabetic mouse model (Fig. 6). Recent evidence has shown that the vascular adventitia, and especially PAT, regulate vascular tone (Gollasch and Dubrovska 2004; Soltis and Cassis 1991), endotheliumdependent vasodilation (Rey et al. 2002), vessel wall thickness (Meng et al. 2006), angiogenesis (Cai et al. 2003; Rehman et al. 2004), and inflammation (Moos et al. 2005; Okamoto et al. 2001; Mazurek et al. 2003). Skeletal muscle is responsible for the majority of whole-body insulin-stimulated glucose disposal and is therefore a relevant target tissue in obesity and type 2 diabetes. The accumulation of adipose tissue interspersed within skeletal muscle and triglycerides within muscle cells are related to insulin resistance, at least in sedentary subjects. Healthy muscle is characterized by the capacity to utilize either lipid or carbohydrate fuels and to switch effectively between these fuels depending on the stimulus and the energy demands. The inflexibility of skeletal muscle to switch between fat and glucose fuels appears to be an important aspect of insulin resistance of skeletal muscle in obesity and type 2 diabetes (Goodpaster and Wolf 2004). 

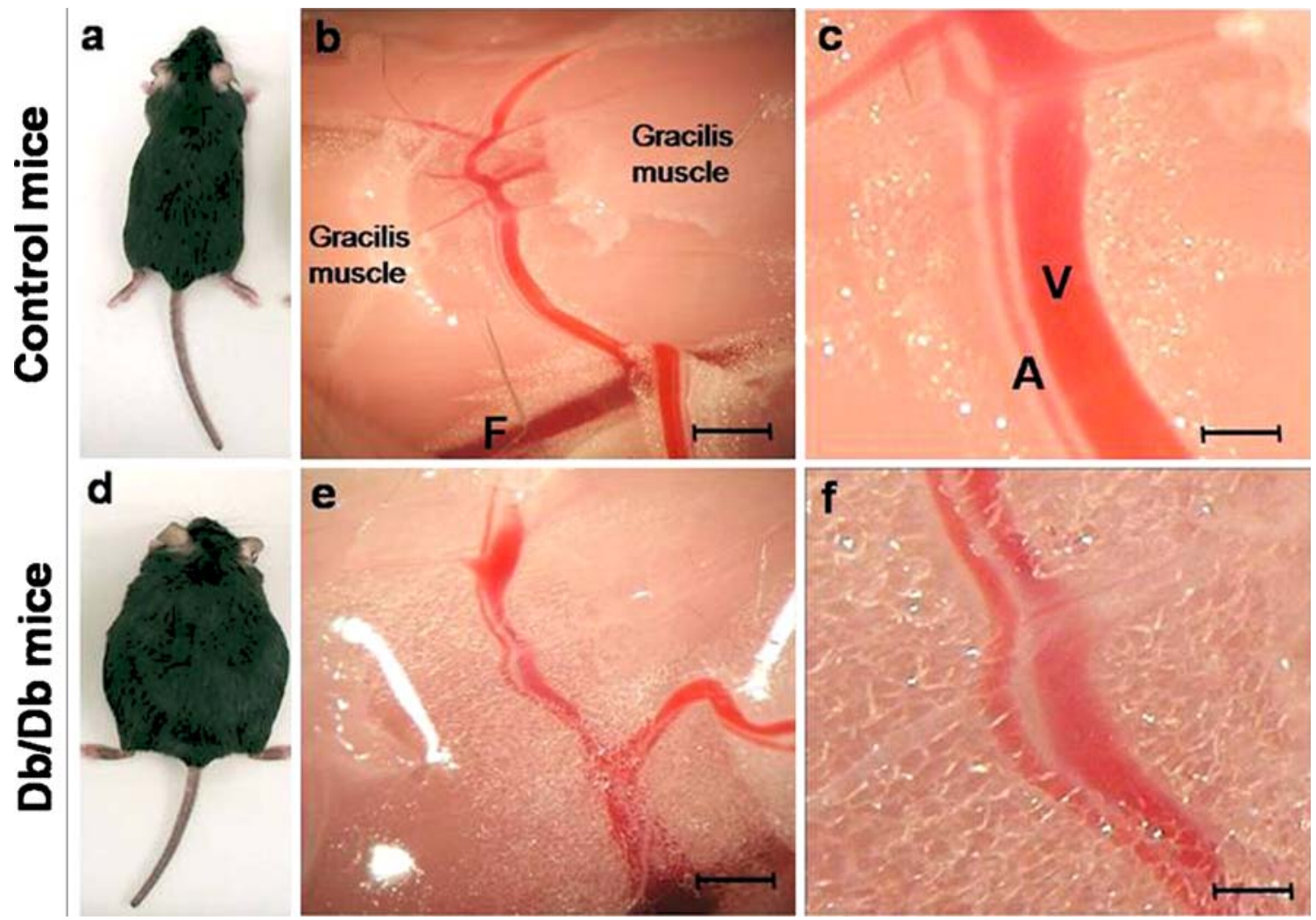

Fig. 6 Increased local perivascular adipose tissue in skeletal muscle arterioles of $\mathrm{Db} / \mathrm{Db}$ mice. After dissection of the gracilis muscle, the vasculature of the corresponding muscle in the control and $\mathrm{Db} / \mathrm{Db}$ mice $(\mathbf{b}, \mathbf{e})$ becomes visible ( $A$ artery, $V$ vein, $F$ femoral artery). At

Taken together, systemic measurements of circulating adipokines probably lead to an underestimation of the actual concentration and damaging effects of locally produced adipokines.

Endothelial dysfunction, type 2 diabetes, and hypertension

Endothelial dysfunction and type 2 diabetes are accompanied by cardiovascular disorders, such as peripheral and coronary arterial disease caused by atherosclerosis, hypertension, and stroke. Endothelial injury reflected in endothelial dysfunction has been indicated as an early hallmark of the development of atherosclerosis (Ross 1999) and hypertension (Serne et al. 2006). It affects the development of type 2 diabetes, whereas the metabolic disturbances of type 2 diabetes in turn further aggravate the progression of these diseases. Similarly, obesity contributes to endothelial dysfunction and metabolic alterations that accelerate the vascular diseases and the occurrence of their clinical complications.

Obese hypertensive humans show insulin-induced vasoconstriction (Gudbjornsdottir et al. 1996), increased ET-1-dependent vasoconstrictor tone, and decreased NO- higher magnification, the artery and vein can be distinguished (c, f). The $\mathrm{Db} / \mathrm{Db}$ mice (d-f) possess more and larger fat cells surrounding the gracilis artery compared with control mice (a-c). Bars $1 \mathrm{~mm}(\mathbf{b}, \mathbf{e})$, $0.25 \mathrm{~mm}(\mathbf{c}, \mathbf{f})$

dependent vasodilator tone at the level of the resistance arteries (Cardillo et al. 2004). In hypertension, the structure and function of the microcirculation are altered (Levy et al. 2001). Blood pressure is inversely related to insulin sensitivity and capillary recruitment, a consequence of reduced endotheliumdependent vasodilation at the pre-capillary level (Serne et al. 1999). Infusion of ET-1 in vivo blunts capillary recruitment and limb blood flow caused by insulin (Ross et al. 2007) and results in increased blood pressure and reduced muscle glucose uptake. In addition, insulin resistance in spontaneously hypertensive rats is associated with endothelial dysfunction characterized by an imbalance between NO and ET-1 production (Potenza et al. 2005).

\section{Conclusion}

Endothelial dysfunction contributes to the generation of insulin resistance and subsequent vascular complications of type 2 diabetes. The close interaction of adipocytes with arteries and arterioles facilitates the exposure of endothelial cells to adipokines, particularly when inflammation activates the adipose tissue, and thus affects vasoregulation and capillary recruitment in skeletal muscle. 
Does endothelial dysfunction precede insulin resistance in type 2 diabetes and obesity?

Dyslipidemia and circulating NEFA aggravate type 2 diabetes and its cardiovascular sequelae (Mazzone et al. 2008). Interestingly, several lines of evidence point to a causal role of endothelial dysfunction in insulin resistance, particularly in muscle. However, the discussion regarding the causal relationship between type 2 diabetes and endothelial dysfunction is complicated, on the one hand, because various endothelial dysfunctions, namely reduced NO production and vasodilation, microalbuminuria, elevated plasma vWF, and low grade inflammatory activation accompanied by increased circulating VCAM and Creactive protein, are independently associated with risk of cardiovascular complications in patients with diabetes and glucose intolerance (Jager et al. 2000). On the other hand, endothelial dysfunction(s) and metabolic dysregulation in these patients probably act mutually on each other, so that the chicken and egg question will be difficult to solve. Notwithstanding, several arguments indicate that endothelial dysfunction as reflected by impaired vasoregulation can indeed contribute to reduced insulin sensitivity in skeletal muscle tissue.

Muscle insulin resistance is the main contributor to reduced insulin action and impaired glucose uptake and, thereby, increased blood glucose levels. Skeletal muscle accounts for $80 \%$ of the insulin-mediated glucose uptake after a meal (DeFronzo 1988) and becomes resistant to insulin in type 2 diabetes and obesity (DeFronzo et al. 1992). Interference with endothelial NO production results in lower insulin sensitivity in striated muscle in both mice and rats (Vincent et al. 2003; Shankar et al. 2000). Furthermore, in obesity, elevated plasma NEFA hinders the ability of insulin to stimulate muscle glucose uptake (Clerk et al. 2002). NEFA also have major effects on microvasculature and activate PKC $\theta$ in the endothelium of resistance arteries and thereby induce insulin-mediated vasoconstriction (Bakker et al. 2008). Other studies have shown that lipid infusion reduces capillary recruitment (de Jongh et al. 2004) and glucose uptake in muscle (Clerk et al. 2002). Hence, both NO production and the response to NEFA by endothelial cells can cause a defect of muscle glucose uptake by an impairment of the microcirculation leading to vasoconstriction. Several other reports have demonstrated a blunted endothelial response before the onset of type 2 diabetes and a reversed effect of endothelial function after the restoration of insulin sensitivity in, for example, obesity-associated insulin resistance. Vascular reactivity (responses to acetylcholine and sodium nitroprusside) in both microcirculation and macrocirculation has been reported to be reduced not only in diabetic subjects, but also in insulin-resistant subjects and relatives of diabetic subjects without increased levels of insulin or glucose. These data support the concept that endothelial dysfunction predicts the development of insulin resistance and diabetes. In addition, elevated plasma levels of biomarkers reflecting endothelial dysfunction, such as E-selectin, ICAM-1, and VCAM-1, are powerful independent predictors of type 2 diabetes in initially healthy people (Meigs et al. 2004).

The mechanisms by which endothelial dysfunction and sub-clinical inflammation may lead to the development of type 2 diabetes are not completely clear. Endothelial dysfunction has been suggested to decrease insulin-mediated capillary recruitment and microvascular redistribution of skeletal muscle blood flow from non-nutritive to nutritive flow paths, limiting insulin availability to skeletal muscle and insulin delivery to the interstitium (Clark et al. 2003). Whatever the mechanism may be, the finding that an improvement in endothelial dysfunction can lead to a decrease in insulin resistance and perhaps to a reduction in the incidence of type 2 diabetes has been appreciated in the secondary analyses of some trials of medications known to improve vascular function (Egashira et al. 1994; Caballero et al. 2004).

Taken together, both metabolic and vascular processes contribute to the development of type 2 diabetes. Notwithstanding a mutual interaction of these aspects during the etiology of diabetes, the initial dysfunction of endothelium contributes to this process, even prior to increased hepatic glucose production (Fig. 7).

\section{Concluding remarks and perspectives}

The foregoing discussion makes clear that endothelial dysfunctions are associated and often causally related to the vascular complications of type 1 and/or 2 diabetes and insulinresistance associated with obesity, in particular those related to the improper generation of ROI, the reduced availability of NO after stimulation by insulin and other vasoactive agents, the low-grade inflammatory activation of the endothelium, and the altered composition of the extracellular matrix.

\section{Hyperglycemia}

Hyperglycemia is an important causal factor in endothelial dysfunction and plays a dominant role in the complications of type 1 diabetes, in particular the development of nephropathy, retinopathy, neuropathy associated with the diabetic foot, and the occurrence of arterial stiffness. Some effects of hyperglycemia are long lasting and provide affected tissues a type of hyperglycemic memory. Early detection of hyperglycemia and the control of plasma glucose levels are important for reducing hyperglycemiainduced vascular complications. 
Fig. 7 Endothelial dysfunction versus type 2 diabetes. Mutual interaction of metabolic and vascular effects contribute to the development of type 2 diabetes, which can be initiated by hyperglycemia, genetic factors, obesity, or other unidentified factors. One possible route by which endothelial dysfunction results in type 2 diabetes is showed in $A-B-C-D$, in which impaired endothelial vasodilation results in a reduction of both capillary recruitment and glucose uptake, with a resulting increase in the levels of blood glucose. A possible route by which type 2 diabetes results in endothelial dysfunction (showed in $1-2-3$ ) is by the formation of reactive oxygen intermediates produced by the glycation pathway
Hyperglycemia

Genetic factors

Obesity

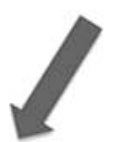

Endothelial

Dysfunction
Type 2

Diabetes

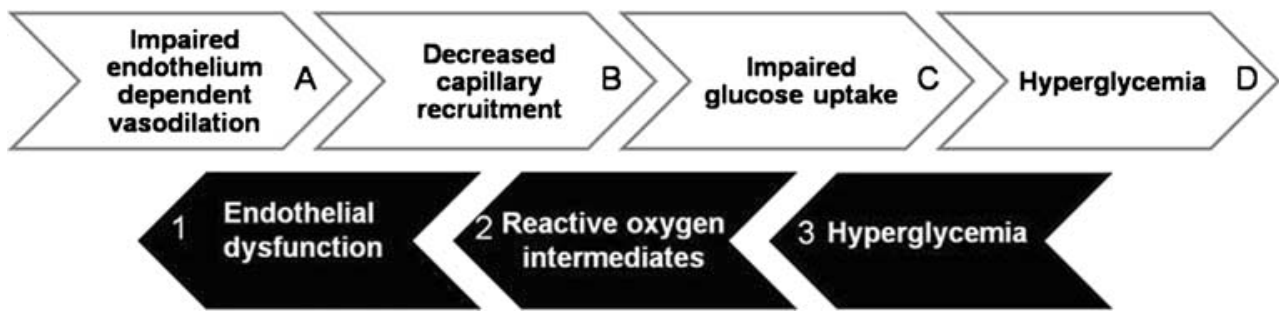

Although the normalization of insulin secretion and the improvement of glucose levels in the circulation by pharmacological treatment or pancreatic island transplantation is the prime approach to reducing the complications of hyperglycemia, the inefficacy of current methods and the occurrence of hyperglycemic memory mean that we have to look for additional treatments. ROI overproduction from mitochondrial electron transport chains serves as a causal link between elevated glucose and three major pathways responsible for hyperglycemic damage, namely the activation of the hexosamine pathway, the increased formation of AGE, and the activation of PKC isoforms. One possible way to reduce ROI is the detoxification of superoxide radicals by increasing superoxide dismutase (SOD). A recent study in mice with overexpression of SOD in their endothelial cells has shown that the progression of diabetic retinopathy in vivo can be suppressed by reducing the expression of VEGF and fibronectin (Goto et al. 2008). Other ways of scavenging ROI or of inhibiting ROI generating NADPH oxidase in vascular cells are presently being evaluated. Another option for reducing hyperglycemia effects is the reduction of glycolysis intermediates by bezotiamine, which appears effective in the mouse eye, or by interfering with specific pathways in the endothelial cells. Inhibition of VEGF in the eye appears promising, whereas the reduction of PKC activation and inhibitors targeted to AGE production reduces vascular complications in diabetic rodents but have not been proven to be effective in man.
Impaired insulin signaling

Despite also being important in type 2 diabetes, the normalization of the plasma glucose concentration has only a small effect on the reduction of cardiovascular disease (peripheral and coronary atherosclerosis, hypertension, and stroke), suggesting that other factors have a larger impact. As outlined above, the improper functioning of the endothelium and blood supply to tissues, such as muscle, has a profound effect on the insulin sensitivity of these tissues and contributes to insulin resistance. In the subsequent chain of reactions that end with overt type 2 diabetes, a mutual interaction between metabolic dysregulation and vascular dysfunction occurs, which is additionally fueled by genetic or acquired dyslipidemia. Normalization of metabolic control and endothelial/vascular function are therefore both required. Furthermore, we have indicated the importance of adipose tissue to vascular functioning. In particular, the extension of perivascular fat directly adjacent to the arterioles and arteries and the enhanced production of adipokines by inflammation of this adipose tissue provide a new paracrine system with a high competence of inducing insulin resistance in the skeletal muscle. Knowledge regarding whether and in what manner the extent and activity of this perivascular fat is influenced by diet and exercise, two important factors in influencing insulin sensitivity, will be of interest.

Various drugs are used to improve insulin sensitivity. In addition to drugs that aim at restoring pancreatic function 
and normalization of blood glucose, ACE inhibitors and PPAR- $\gamma$ agonists, such as thiazolidinediones (TZD), are regularly employed to treat diabetes mellitus type 2 . ACE inhibitors reduce the conversion of angiotensin 1 into the potent angiotensin 2 and simultaneously reduce the breakdown of the vasoactive agent bradykinin. These inhibitors have an improving effect on nephropathy and cardiovascular complications in all diabetes patients. The main beneficial effects of TZD are the improvement of insulin sensitivity and glucose tolerance, the generation of small insulin-sensitive adipocytes, and a decrease in inflammation markers (Cock et al. 2004; Picard and Auwerx 2002). TZD lead to an improvement in vascular function through either a direct effect on the vascular wall or by reducing the release of adipokines by adipose tissue (Tonelli et al. 2004). Statins, which in addition to lowering plasma LDL cholesterol, also reduce ROI production in endothelial cells and improve endothelial function, are also known to reduce cardiovascular disease in diabetes patients (Costa et al. 2006).

Another way to improve insulin sensitivity is to inhibit the negative effects of adipokines on the induction of insulin-mediated vasoconstriction. In isolated arteries, we have shown that the insulin-mediated vasconstriction induced by either TNF $\alpha$ or FFA can be abolished by the inhibition of JNK or PKC $\theta$ activation, respectively (Bakker et al. 2008; Eringa et al. 2006). Furthermore, mice models with a genetic deletion of JNK or PKC $\theta$ are protected from diet-induced insulin resistance. This makes JNK and PKC $\theta$ good targets for improving insulin sensitivity.

\section{Obesity and endothelial dysfunction}

As obesity contributes to insulin resistance and endothelial dysfunction, the reduction of circulating NEFA and weight loss by diet and/or exercise or surgery can be used to improve endothelial function in obesity. Overnight lowering of FFA in obese women improves capillary recruitment, independently from endothelial-dependent vasodilation, whereas FFA elevation in lean subjects reduces both capillary recruitment and endothelial vasodilation (de Jongh et al. 2004). Hence, acute reduction in FFA levels is not sufficient to improve endothelial function. In contrast, weight loss is associated with a reduction of the long-term total mortality from diabetes and heart disease (Adams et al. 2007), an improvement of insulin sensitivity, a decrease in insulin production (Schernthaner and Morton 2008), and an improvement of flow-mediated vasodilation (Williams et al. 2005). Most studies of the effect of weight loss by either a low caloric diet (Sasaki et al. 2002; Raitakari et al. 2004), diet, and exercise (Sciacqua et al. 2003), or diet and medication (Bergholm et al. 2003) has shown positive effects on endothelial dysfunction. Furthermore, Woo et al.
(2004) have demonstrated that the improvement in arterial endothelial function is greater in diet plus exercise groups compared with diet alone groups, because of an independent effect of exercise training on improved arterial function. Exercise is well known to have a positive effect on endothelial function, and the additional improvement in endothelial function by diet plus exercise is therefore unsurprising. Even in hyperglycaemic obese mice, which have totally blunted endothelial responses from birth, exercise reverses vascular endothelial dysfunction (Moien-Afshari et al. 2008).

Taken together, the effect of adipokines from adipose tissue adjacent to the vessel wall is an important contributor to endothelial dysfunction. An understanding of intervention at the level of adipocytes and/or endothelial cells may thus improve the treatment of metabolic disorders.

Open Access This article is distributed under the terms of the Creative Commons Attribution Noncommercial License which permits any noncommercial use, distribution, and reproduction in any medium, provided the original author(s) and source are credited.

\section{References}

Adams TD, Gress RE, Smith SC, Halverson RC, Simper SC, Rosamond WD, LaMonte MJ, Stroup AM, Hunt SC (2007) Long-term mortality after gastric bypass surgery. N Engl J Med 357:753-761

Aiello LP (2005) Angiogenic pathways in diabetic retinopathy. N Engl J Med 353:839-841

Aiello LP, Avery RL, Arrigg PG, Keyt BA, Jampel HD, Shah ST, Pasquale LR, Thieme H, Iwamoto MA, Park JE (1994) Vascular endothelial growth factor in ocular fluid of patients with diabetic retinopathy and other retinal disorders. N Engl J Med 331:14801487

Aird WC (2007a) Phenotypic heterogeneity of the endothelium. I. Structure, function, and mechanisms. Circ Res 100:158-173

Aird WC (2007b) Phenotypic heterogeneity of the endothelium. II. Representative vascular beds. Circ Res 100:174-190

Aizawa-Abe M, Ogawa Y, Masuzaki H, Ebihara K, Satoh N, Iwai H, Matsuoka N, Hayashi T, Hosoda K, Inoue G, Yoshimasa Y, Nakao K (2000) Pathophysiological role of leptin in obesityrelated hypertension. J Clin Invest 105:1243-1252

Al Suwaidi J, Higano ST, Holmes DR, Lennon R, Lerman A (2001) Obesity is independently associated with coronary endothelial dysfunction in patients with normal or mildly diseased coronary arteries. J Am Coll Cardiol 37:1523-1528

Alessi MC, Juhan-Vague I (2008) Metabolic syndrome, haemostasis and thrombosis. Thromb Haemost 99:995-1000

American Diabetes Association (2005) Standards of medical care in diabetes. Diabetes Care 28:S4-36

Andreoli CM, Miller JW (2007) Anti-vascular endothelial growth factor therapy for ocular neovascular disease. Curr Opin Ophthalmol 18:502-508

Arita Y, Kihara S, Ouchi N, Takahashi M, Maeda K, Miyagawa Ji, Hotta K, Shimomura I, Nakamura T, Miyaoka K, Kuriyama H, Nishida M, Yamashita S, Okubo K, Matsubara K, Muraguchi M, Ohmoto Y, Funahashi T, Matsuzawa Y (1999) Paradoxical 
decrease of an adipose-specific protein, adiponectin, in obesity. Biochem Biophys Res Commun 257:79-83

Austin RC, Lentz SR, Werstuck GH (2004) Role of hyperhomocysteinemia in endothelial dysfunction and atherothrombotic disease. Cell Death Differ 1 (11 Suppl):S56-S64

Bagi Z, Koller A, Kaley G (2003) Superoxide-NO interaction decreases flow- and agonist-induced dilations of coronary arterioles in type 2 diabetes mellitus. Am J Physiol Heart Circ Physiol 285:H1404-H1410

Bakker W, Sipkema P, Stehouwer CD, Serne EH, Smulders YM, Hinsbergh VW van, Eringa EC (2008) Protein kinase C theta activation induces insulin-mediated constriction of muscle resistance arteries. Diabetes 57:706-713

Becker A, Hinsbergh VW van, Jager A, Kostense PJ, Dekker JM, Nijpels G, Heine RJ, Bouter LM, Stehouwer CD (2002) Why is soluble intercellular adhesion molecule-1 related to cardiovascular mortality? Eur J Clin Invest 32:1-8

Beltowski J, Wojcicka G, Jamroz A (2003) Stimulatory effect of leptin on nitric oxide production is impaired in dietary-induced obesity. Obes Res 11:1571-1580

Berg BM van den, Nieuwdorp M, Stroes ES, Vink H (2006) Glycocalyx and endothelial (dys) function: from mice to men. Pharmacol Rep 58 (Suppl):75-80

Bergholm R, Tiikkainen M, Vehkavaara S, Tamminen M, Teramo K, Rissanen A, Yki-Jarvinen H (2003) Lowering of LDL cholesterol rather than moderate weight loss improves endothelium-dependent vasodilatation in obese women with previous gestational diabetes. Diabetes Care 26:1667-1672

Berkowitz DE, White R, Li D, Minhas KM, Cernetich A, Kim S, Burke S, Shoukas AA, Nyhan D, Champion HC, Hare JM (2003) Arginase reciprocally regulates nitric oxide synthase activity and contributes to endothelial dysfunction in aging blood vessels. Circulation 108:2000-2006

Beyer AM, Baumbach GL, Halabi CM, Modrick ML, Lynch CM, Gerhold TD, Ghoneim SM, Lange WJ de, Keen HL, Tsai YS, Maeda N, Sigmund CD, Faraci FM (2008) Interference with PPAR \{gamma\} signaling causes cerebral vascular dysfunction, hypertrophy, and remodeling. Hypertension 51:867-871

Bornstein SR, Abu-Asab M, Glasow A, Path G, Hauner H, Tsokos M, Chrousos GP, Scherbaum WA (2000) Immunohistochemical and ultrastructural localization of leptin and leptin receptor in human white adipose tissue and differentiating human adipose cells in primary culture. Diabetes 49:532-538

Bottaro DP, Bonner-Weir S, King GL (1989) Insulin receptor recycling in vascular endothelial cells. Regulation by insulin and phorbol ester. J Biol Chem 264:5916-5923

Bouloumie A, Drexler HCA, Lafontan M, Busse R (1998) Leptin, the product of Ob gene, promotes angiogenesis. Circ Res 83:1059-1066

Brook RD, Bard RL, Rubenfire M, Ridker PM, Rajagopalan S (2001) Usefulness of visceral obesity (waist/hip ratio) in predicting vascular endothelial function in healthy overweight adults. Am J Cardiol 88:1264-1269

Brownlee M (2001) Biochemistry and molecular cell biology of diabetic complications. Nature 414:813-820

Brownlee M (2005) The pathobiology of diabetic complications: a unifying mechanism. Diabetes 54:1615-1625

Caballero AE, Arora S, Saouaf R, Lim SC, Smakowski P, Park JY, King GL, LoGerfo FW, Horton ES, Veves A (1999) Microvascular and macrovascular reactivity is reduced in subjects at risk for type 2 diabetes. Diabetes 48:1856-1862

Caballero AE, Delgado A, Aguilar-Salinas CA, Herrera AN, Castillo JL, Cabrera T, Gomez-Perez FJ, Rull JA (2004) The differential effects of metformin on markers of endothelial activation and inflammation in subjects with impaired glucose tolerance: a placebo-controlled, randomized clinical trial. J Clin Endocrinol Metab 89:3943-3948
Cai WJ, Koltai S, Kocsis E, Scholz D, Kostin S, Luo X, Schaper W, Schaper J (2003) Remodeling of the adventitia during coronary arteriogenesis. Am J Physiol Heart Circ Physiol 284:H31-H40

Caporali A, Pani E, Horrevoets AJ, Kraenkel N, Oikawa A, Sala-Newby GB, Meloni M, Cristofaro B, Graiani G, Leroyer AS, Boulanger CM, Spinetti G, Yoon SO, Madeddu P, Emanueli C (2008) Neurotrophin p75 receptor (p75NTR) promotes endothelial cell apoptosis and inhibits angiogenesis: implications for diabetesinduced impaired neovascularization in ischemic limb muscles. Circ Res 103:e15-e26

Cardillo C, Nambi SS, Kilcoyne CM, Choucair WK, Katz A, Quon MJ, Panza JA (1999) Insulin stimulates both endothelin and nitric oxide activity in the human forearm. Circulation 100:820-825

Cardillo C, Campia U, Iantorno M, Panza JA (2004) Enhanced vascular activity of endogenous endothelin-1 in obese hypertensive patients. Hypertension 43:36-40

Carmeliet P (2005) Angiogenesis in life, disease and medicine. Nature 438:932-936

Castillo C, Bogardus C, Bergman R, Thuillez P, Lillioja S (1994) Interstitial insulin concentrations determine glucose uptake rates but not insulin resistance in lean and obese men. J Clin Invest 93:10-16

Ceradini DJ, Yao D, Grogan RH, Callaghan MJ, Edelstein D, Brownlee M, Gurtner GC (2008) Decreasing intracellular superoxide corrects defective ischemia-induced new vessel formation in diabetic mice. J Biol Chem 283:10930-10938

Cersosimo E, DeFronzo RA (2006) Insulin resistance and endothelial dysfunction: the road map to cardiovascular diseases. Diabetes Metab Res Rev 22:423-436

Chen H, Montagnani M, Funahashi T, Shimomura I, Quon MJ (2003) Adiponectin stimulates production of nitric oxide in vascular endothelial cells. J Biol Chem 278:45021-45026

Chen K, Li F, Li J, Cai H, Strom S, Bisello A, Kelley DE, Friedman-Einat M, Skibinski GA, McCrory MA, Szalai AJ, Zhao AZ (2006) Induction of leptin resistance through direct interaction of C-reactive protein with leptin. Nat Med 12:425-432

Chen S, Hong SW, Iglesias-de la Cruz MC, Isono M, Casaretto A, Ziyadeh FN (2001) The key role of the transforming growth factor-beta system in the pathogenesis of diabetic nephropathy. Ren Fail 23:471-481

Cines DB, Pollak ES, Buck CA, Loscalzo J, Zimmerman GA, McEver RP, Pober JS, Wick TM, Konkle BA, Schwartz BS, Barnathan ES, McCrae KR, Hug BA, Schmidt AM, Stern DM (1998) Endothelial cells in physiology and in the pathophysiology of vascular disorders. Blood 91:3527-3561

Clark MG, Wallis MG, Barrett EJ, Vincent MA, Richards SM, Clerk LH, Rattigan S (2003) Blood flow and muscle metabolism: a focus on insulin action. Am J Physiol Endocrinol Metab 284: E241-E258

Clement K, Vaisse C, Lahlou N, Cabrol S, Pelloux V, Cassuto D, Gourmelen M, Dina C, Chambaz J, Lacorte JM, Basdevant A, Bougneres P, Lebouc Y, Froguel P, Guy-Grand B (1998) A mutation in the human leptin receptor gene causes obesity and pituitary dysfunction. Nature 392:398-401

Clerk LH, Rattigan S, Clark MG (2002) Lipid infusion impairs physiologic insulin-mediated capillary recruitment and muscle glucose uptake in vivo. Diabetes 51:1138-1145

Cock TA, Houten SM, Auwerx J (2004) Peroxisome proliferatoractivated receptor-\{gamma\}: too much of a good thing causes harm. EMBO Reports 5:142-147

Coleman DL (1979) Obesity genes: beneficial effects in heterozygous mice. Science 203:663-665

Combs TP, Wagner JA, Berger J, Doebber T, Wang WJ, Zhang BB, Tanen M, Berg AH, O'Rahilly S, Savage DB, Chatterjee K, Weiss S, Larson PJ, Gottesdiener KM, Gertz BJ, Charron MJ, 
Scherer PE, Moller DE (2002) Induction of adipocyte complement-related protein of 30 kilodaltons by PPAR \{gamma\} agonists: a potential mechanism of insulin sensitization. Endocrinology 143:998-1007

Coppack SW (2001) Pro-inflammatory cytokines and adipose tissue. Proc Nutr Soc 60:349-356

Correia ML, Haynes WG, Rahmouni K, Morgan DA, Sivitz WI, Mark AL (2002) The concept of selective leptin resistance: evidence from agouti yellow obese mice. Diabetes 51:439-442

Costa J, Borges M, David C, Vaz Carneiro A (2006) Efficacy of lipid lowering drug treatment for diabetic and non-diabetic patients: meta-analysis of randomised controlled trials. BMJ 332:11151124

Cybulsky MI, Gimbrone MA Jr (1991) Endothelial expression of a mononuclear leukocyte adhesion molecule during atherogenesis. Science 251:788-791

D’Amico G, Bazzi C (2003) Pathophysiology of proteinuria. Kidney Int 63:809-825

Date H, Imamura T, Ideguchi T, Kawagoe J, Sumi T, Masuyama H, Onitsuka H, Ishikawa T, Nagoshi T, Eto T (2006) Adiponectin produced in coronary circulation regulates coronary flow reserve in nondiabetic patients with angiographically normal coronary arteries. Clin Cardiol 29:211-214

Davda RK, Stepniakowski KT, Lu G, Ullian ME, Goodfriend TL, Egan BM (1995) Oleic acid inhibits endothelial nitric oxide synthase by a protein kinase $\mathrm{C}$-independent mechanism. Hypertension 26:764-770

De Vriese AS, Verbeuren TJ, Van de Voorde J, Lameire NH, Vanhoutte PM (2000) Endothelial dysfunction in diabetes. Br J Pharmacol 130:963-974

Deckert T, Feldt-Rasmussen B, Borch-Johnsen K, Jensen T, KofoedEnevoldsen A (1989) Albuminuria reflects widespread vascular damage. The steno hypothesis. Diabetologia 32:219-226

DeFronzo RA (1988) Lilly lecture 1987. The triumvirate: beta-cell, muscle, liver. A collusion responsible for NIDDM. Diabetes 37:667-687

DeFronzo RA, Bonadonna RC, Ferrannini E (1992) Pathogenesis of NIDDM. A balanced overview. Diabetes Care 15:318-368

Dekker RJ, Thienen JV van, Rohlena J, Jager SC de, Elderkamp YW, Seppen J, Vries CJ de, Biessen EA, Berkel TJ van, Pannekoek H, Horrevoets AJ (2005) Endothelial KLF2 links local arterial shear stress levels to the expression of vascular tone-regulating genes. Am J Pathol 167:609-618

Dickhout JG, Hossain GS, Pozza LM, Zhou J, Lhotak S, Austin RC (2005) Peroxynitrite causes endoplasmic reticulum stress and apoptosis in human vascular endothelium: implications in atherogenesis. Arterioscler Thromb Vasc Biol 25:2623-2629

Du XL, Edelstein D, Rossetti L, Fantus IG, Goldberg H, Ziyadeh F, Wu J, Brownlee M (2000) Hyperglycemia-induced mitochondrial superoxide overproduction activates the hexosamine pathway and induces plasminogen activator inhibitor-1 expression by increasing Sp1 glycosylation. Proc Natl Acad Sci USA 97:12222-12226

Dworakowski R, Alom-Ruiz SP, Shah AM (2008) NADPH oxidasederived reactive oxygen species in the regulation of endothelial phenotype. Pharmacol Rep 60:21-28

Egashira K, Hirooka Y, Kai H, Sugimachi M, Suzuki S, Inou T, Takeshita A (1994) Reduction in serum cholesterol with pravastatin improves endothelium-dependent coronary vasomotion in patients with hypercholesterolemia. Circulation 89:2519-2524

Eizirik DL, Cardozo AK, Cnop M (2008) The role for endoplasmic reticulum stress in diabetes mellitus. Endocr Rev 29:42-61

Engerman RL, Kern TS (1987) Progression of incipient diabetic retinopathy during good glycemic control. Diabetes 36:808-812

Erdei N, Toth A, Pasztor ET, Papp Z, Edes I, Koller A, Bagi Z (2006) High-fat diet-induced reduction in nitric oxide-dependent arteri- olar dilation in rats: role of xanthine oxidase-derived superoxide anion. Am J Physiol Heart Circ Physiol 291:H2107-H2115

Eringa EC, Stehouwer CDA, Walburg K, Clark AD, Nieuw Amerongen GP, Westerhof N, Sipkema P (2006) Physiological concentrations of insulin induce endothelin-dependent vasoconstriction of skeletal muscle resistance arteries in the presence of tumor necrosis factor-\{alpha\} dependence on c-jun n-terminal kinase. Arterioscler Thromb Vasc Biol 26:274-280

Eringa EC, Stehouwer CDA, Roos MH, Westerhof N, Sipkema P (2007) Selective resistance to vasoactive effects of insulin in muscle resistance arteries of obese Zucker (fa/fa) rats. Am J Physiol Endocrinol Metab 293:E1134-E1139

Esposito K, Pontillo A, Di Palo C, Giugliano G, Masella M, Marfella R, Giugliano D (2003) Effect of weight loss and lifestyle changes on vascular inflammatory markers in obese women: a randomized trial. JAMA 289:1799-1804

Ferri C, Pittoni V, Piccoli A, Laurenti O, Cassone MR, Bellini C, Properzi G, Valesini G, De Mattia G, Santucci A (1995) Insulin stimulates endothelin-1 secretion from human endothelial cells and modulates its circulating levels in vivo. J Clin Endocrinol Metab $80: 829-835$

Fioretto P, Steffes MW, Sutherland DE, Goetz FC, Mauer M (1998) Reversal of lesions of diabetic nephropathy after pancreas transplantation. N Engl J Med 339:69-75

Fitzgerald SM, Kemp-Harper BK, Parkington HC, Head GA, Evans RG (2007) Endothelial dysfunction and arterial pressure regulation during early diabetes in mice: roles for nitric oxide and endothelium-derived hyperpolarizing factor. Am J Physiol Regul Integr Comp Physiol 293:R707-R713

Forbes JM, Coughlan MT, Cooper ME (2008) Oxidative stress as a major culprit in kidney disease in diabetes. Diabetes 57:14461454

Galili O, Versari D, Sattler KJ, Olson ML, Mannheim D, McConnell JP, Chade AR, Lerman LO, Lerman A (2007) Early experimental obesity is associated with coronary endothelial dysfunction and oxidative stress. Am J Physiol Heart Circ Physiol 292:H904 H911

Gharavi NM, Gargalovic PS, Chang I, Araujo JA, Clark MJ, Szeto WL, Watson AD, Lusis AJ, Berliner JA (2007) High-density lipoprotein modulates oxidized phospholipid signaling in human endothelial cells from proinflammatory to anti-inflammatory. Arterioscler Thromb Vasc Biol 27:1346-1353

Gimbrone MA Jr (1999) Endothelial dysfunction, hemodynamic forces, and atherosclerosis. Thromb Haemost 82:722-726

Goldfine AB, Beckman JA, Betensky RA, Devlin H, Hurley S, Varo N, Schonbeck U, Patti ME, Creager MA (2006) Family history of diabetes is a major determinant of endothelial function. J Am Coll Cardiol 47:2456-2461

Gollasch M, Dubrovska G (2004) Paracrine role for periadventitial adipose tissue in the regulation of arterial tone. Trends Pharmacol Sci 25:647-653

Goodpaster BH, Wolf D (2004) Skeletal muscle lipid accumulation in obesity, insulin resistance, and type 2 diabetes. Pediatr Diabetes $5: 219-226$

Goto H, Nishikawa T, Sonoda K, Kondo T, Kukidome D, Fujisawa K, Yamashiro T, Motoshima H, Matsumura T, Tsuruzoe K, Araki E (2008) Endothelial MnSOD overexpression prevents retinal VEGF expression in diabetic mice. Biochem Biophys Res Commun 366:814-820

Gudbjornsdottir S, Elam M, Sellgren J, Anderson EA (1996) Insulin increases forearm vascular resistance in obese, insulin-resistant hypertensives. J Hypertens 14:91-97

Haaren PM van, VanBavel E, Vink H, Spaan JA (2003) Localization of the permeability barrier to solutes in isolated arteries by confocal microscopy. Am J Physiol Heart Circ Physiol 285: H2848-H2856 
Hagenfeldt L, Dahlquist G, Persson B (1989) Plasma amino acids in relation to metabolic control in insulin-dependent diabetic children. Acta Paediatr Scand 78:278-282

Hammes HP, Du X, Edelstein D, Taguchi T, Matsumura T, Ju Q, Lin J, Bierhaus A, Nawroth P, Hannak D, Neumaier M, Bergfeld R, Giardino I, Brownlee M (2003) Benfotiamine blocks three major pathways of hyperglycemic damage and prevents experimental diabetic retinopathy. Nat Med 9:294-299

Hart GW, Housley MP, Slawson C (2007) Cycling of O-linked [beta]$\mathrm{N}$-acetylglucosamine on nucleocytoplasmic proteins. Nature 446:1017-1022

Harte AL, McTernan PG, McTernan CL, Crocker J, Starcynski J, Barnett AH, Matyka K, Kumar S (2003a) Insulin increases angiotensinogen expression in human abdominal subcutaneous adipocytes. Diabetes Obes Metab 5:462-467

Harte AL, McTernan PG, McTernan CL, Smith SA, Barnett AH, Kumar S (2003b) Rosiglitazone inhibits the insulin-mediated increase in PAI-1 secretion in human abdominal subcutaneous adipocytes. Diabetes Obes Metab 5:302-310

Hattori Y, Suzuki M, Hattori S, Kasai K (2003) Globular adiponectin upregulates nitric oxide production in vascular endothelial cells. Diabetologia 46:1543-1549

Hauner H (2004) The new concept of adipose tissue function. Physiol Behav 83:653-658

Heickendorff L, Ledet T, Rasmussen LM (1994) Glycosaminoglycans in the human aorta in diabetes mellitus: a study of tunica media from areas with and without atherosclerotic plaque. Diabetologia 37:286-292

Heitzer T, Krohn K, Albers S, Meinertz T (2000) Tetrahydrobiopterin improves endothelium-dependent vasodilation by increasing nitric oxide activity in patients with type II diabetes mellitus. Diabetologia 43:1435-1438

Hinsbergh VW van (2001) The endothelium: vascular control of haemostasis. Eur J Obstet Gynecol Reprod Biol 95:198-201

Hodnett BL, Hester RL (2007) Regulation of muscle blood flow in obesity. Microcirculation 14:273-288

Hogeboom van Buggenum IM, Polak BC, Reichert-Thoen JW, Vries-Knoppert WA de, Hinsbergh VW van, Tangelder GJ. (2002) Angiotensin converting enzyme inhibiting therapy is associated with lower vitreous vascular endothelial growth factor concentrations in patients with proliferative diabetic retinopathy. Diabetologia 45:203-209

Hotamisligil GS (2005) Role of endoplasmic reticulum stress and c-jun nh2-terminal kinase pathways in inflammation and origin of obesity and diabetes. Diabetes 54:S73-S78

Hotamisligil GS, Shargill NS, Spiegelman BM (1993) Adipose expression of tumor necrosis factor-alpha: direct role in obesitylinked insulin resistance. Science 259:87-91

Hotamisligil GS, Arner P, Caro JF, Atkinson RL, Spiegelman BM (1995) Increased adipose tissue expression of tumor necrosis factor-alpha in human obesity and insulin resistance. J Clin Invest 95:2409-2415

Hotta K, Funahashi T, Arita Y, Takahashi M, Matsuda M, Okamoto Y, Iwahashi H, Kuriyama H, Ouchi N, Maeda K, Nishida M, Kihara S, Sakai N, Nakajima T, Hasegawa K, Muraguchi M, Ohmoto Y, Nakamura T, Yamashita S, Hanafusa T, Matsuzawa Y (2000) Plasma concentrations of a novel, adipose-specific protein, adiponectin, in type 2 diabetic patients. Arterioscler Thromb Vasc Biol 20:1595-1599

Hui YY, McAmis WC, Baynes JW, Schaeffer RC Jr, Wolf MB (2001) Effect of advanced glycation end products on oxidative stress in endothelial cells in culture: a warning on the use of cells studied in serum-free media. Diabetologia 44:1310-1317

Jager A, Hinsbergh VW van, Kostense PJ, Emeis JJ, Yudkin JS, Nijpels G, Dekker JM, Heine RJ, Bouter LM, Stehouwer CD (1999) von Willebrand factor, C-reactive protein, and 5-year mortality in diabetic and nondiabetic subjects: the Hoorn study. Arterioscler Thromb Vasc Biol 19:3071-3078

Jager A, Hinsbergh VW van, Kostense PJ, Emeis JJ, Nijpels G, Dekker JM, Heine RJ, Bouter LM, Stehouwer CD (2000) Increased levels of soluble vascular cell adhesion molecule 1 are associated with risk of cardiovascular mortality in type 2 diabetes: the Hoorn study. Diabetes 49:485-491

Jensen JS, Borch-Johnsen K, Jensen G, Feldt-Rasmussen B (1995) Microalbuminuria reflects a generalized transvascular albumin leakiness in clinically healthy subjects. Clin Sci (Lond) 88:629 633

Jiang ZY, Lin YW, Clemont A, Feener EP, Hein KD, Igarashi M, Yamauchi T, White MF, King GL (1999) Characterization of selective resistance to insulin signaling in the vasculature of obese zucker (fa/fa) rats. J Clin Invest 104:447-457

Jongh RT de, Serne EH, IJzerman RG, Vries G de, Stehouwer CDA (2004) Free fatty acid levels modulate microvascular function: relevance for obesity-associated insulin resistance, hypertension, and microangiopathy. Diabetes 53:2873-2882

Jongh RT de, Ijzerman RG, Serne EH, Voordouw JJ, Yudkin JS, Waal HAD de, Stehouwer CDA, Weissenbruch MM van (2006) Visceral and truncal subcutaneous adipose tissue are associated with impaired capillary recruitment in healthy individuals. J Clin Endocrinol Metab 91:5100-5106

Kaesemeyer WH, Ogonowski AA, Jin L, Caldwell RB, Caldwell RW (2000) Endothelial nitric oxide synthase is a site of superoxide synthesis in endothelial cells treated with glyceryl trinitrate. Br J Pharmacol 131:1019-1023

Kim F, Gallis B, Corson MA (2001) TNF-\{alpha\} inhibits flow and insulin signaling leading to NO production in aortic endothelial cells. Am J Physiol Cell Physiol 280:C1057-C1065

Kim F, Tysseling KA, Rice J, Gallis B, Haji L, Giachelli CM, Raines EW, Corson MA, Schwartz MW (2005a) Activation of IKK\&\#x03b2; by glucose is necessary and sufficient to impair insulin signaling and nitric oxide production in endothelial cells. J Mol Cell Cardiol 39:327-334

Kim F, Tysseling KA, Rice J, Pham M, Haji L, Gallis BM, Baas AS, Paramsothy P, Giachelli CM, Corson MA, Raines EW (2005b) Free fatty acid impairment of nitric oxide production in endothelial cells is mediated by IKK $\{$ beta $\}$. Arterioscler Thromb Vasc Biol 25:989-994

Kim JK, Fillmore JJ, Sunshine MJ, Albrecht B, Higashimori T, Kim DW, Liu ZX, Soos TJ, Cline GW, O'Brien WR, Littman DR, Shulman GI (2004) PKC-\{theta\} knockout mice are protected from fat-induced insulin resistance. J Clin Invest 114:823-827

King GL (1996) The role of hyperglycaemia and hyperinsulinaemia in causing vascular dysfunction in diabetes. Ann Med 28:427-432

Kliewer SA, Xu HE, Lambert MH, Willson TM (2001) Peroxisome proliferator-activated receptors: from genes to physiology. Recent Prog Horm Res 56:239-265

Kobashi C, Urakaze M, Kishida M, Kibayashi E, Kobayashi H, Kihara S, Funahashi T, Takata M, Temaru R, Sato A, Yamazaki K, Nakamura N, Kobayashi M (2005) Adiponectin inhibits endothelial synthesis of interleukin-8. Circ Res 97:1245-1252

Koya D, King GL (1998) Protein kinase C activation and the development of diabetic complications. Diabetes 47:859-866

Krzyzanowska K, Mittermayer F, Wolzt M, Schernthaner G (2007) Asymmetric dimethylarginine predicts cardiovascular events in patients with type 2 diabetes. Diabetes Care 30:1834-1839

Kubota T, Kubota N, Moroi M, Terauchi Y, Kobayashi T, Kamata K, Suzuki R, Tobe K, Namiki A, Aizawa S, Nagai R, Kadowaki T, Yamaguchi T (2003) Lack of insulin receptor substrate-2 causes progressive neointima formation in response to vessel injury. Circulation 107:3073-3080

Kume N, Cybulsky MI, Gimbrone MA Jr (1992) Lysophosphatidylcholine, a component of atherogenic lipoproteins, induces 
mononuclear leukocyte adhesion molecules in cultured human and rabbit arterial endothelial cells. J Clin Invest 90:1138-1144

Lajer M, Tarnow L, Jorsal A, Teerlink T, Parving HH, Rossing P (2008) Plasma concentration of asymmetric dimethylarginine (ADMA) predicts cardiovascular morbidity and mortality in type 1 diabetic patients with diabetic nephropathy. Diabetes Care 31:747-752

Laviola L, Belsanti G, Davalli AM, Napoli R, Perrini S, Weir GC, Giorgino R, Giorgino F (2001) Effects of streptozocin diabetes and diabetes treatment by islet transplantation on in vivo insulin signaling in rat heart. Diabetes 50:2709-2720

Levy BI, Ambrosio G, Pries AR, Struijker-Boudier HAJ (2001) Microcirculation in hypertension: a new target for treatment? Circulation 104:735-740

Li G, Barrett EJ, Barrett MO, Cao W, Liu Z (2007) Tumor necrosis factor- $\{a \mid p h a\}$ induces insulin resistance in endothelial cells via a $\mathrm{p} 38$ mitogen-activated protein kinase-dependent pathway. Endocrinology 148:3356-3363

Lieuw-a-Fa ML, Schalkwijk CG, Engelse M, Hinsbergh VW van (2006) Interaction of Nepsilon(carboxymethyl)lysine- and methylglyoxal-modified albumin with endothelial cells and macrophages. Splice variants of RAGE may limit the responsiveness of human endothelial cells to AGEs. Thromb Haemost 95:320-328

Lin KY, Ito A, Asagami T, Tsao PS, Adimoolam S, Kimoto M, Tsuji H, Reaven GM, Cooke JP (2002) Impaired nitric oxide synthase pathway in diabetes mellitus: role of asymmetric dimethylarginine and dimethylarginine dimethylaminohydrolase. Circulation 106:987-992

Lundman P, Tornvall P, Nilsson L, Pernow J (2001) A triglyceriderich fat emulsion and free fatty acids but not very low density lipoproteins impair endothelium-dependent vasorelaxation. Atherosclerosis 159:35-41

Luo D, He Y, Zhang H, Yu L, Chen H, Xu Z, Tang S, Urano F, Min W (2008) AIP1 is critical in transducing IRE1-mediated endoplasmic reticulum stress response. J Biol Chem 283:11905-11912

Marshall S, Bacote V, Traxinger RR (1991) Discovery of a metabolic pathway mediating glucose-induced desensitization of the glucose transport system. Role of hexosamine biosynthesis in the induction of insulin resistance. J Biol Chem 266:4706-4712

Martin A, Komada MR, Sane DC (2003) Abnormal angiogenesis in diabetes mellitus. Med Res Rev 23:117-145

Marx N, Bourcier T, Sukhova GK, Libby P, Plutzky J (1999) PPAR \{gamma\} activation in human endothelial cells increases plasminogen activator inhibitor type-1 expression: PPAR \{gamma\} as a potential mediator in vascular disease. Arterioscler Thromb Vasc Biol 19:546-551

Mazurek T, Zhang L, Zalewski A, Mannion JD, Diehl JT, Arafat H, Sarov-Blat L, O'Brien S, Keiper EA, Johnson AG, Martin J, Goldstein BJ, Shi Y (2003) Human epicardial adipose tissue is a source of inflammatory mediators. Circulation 108:2460-2466

Mazzone T, Chait A, Plutzky J (2008) Cardiovascular disease risk in type 2 diabetes mellitus: insights from mechanistic studies. Lancet 371:1800-1809

Meigs JB, Hu FB, Rifai N, Manson JE (2004) Biomarkers of endothelial dysfunction and risk of type 2 diabetes mellitus. JAMA 291:1978-1986

Meng QH, Jamal W, Hart SL, McEwan JR (2006) Application to vascular adventitia of a nonviral vector for TIMP-1 gene therapy to prevent intimal hyperplasia. Hum Gene Ther 17:717-727

Minokoshi Y, Kim YB, Peroni OD, Fryer LGD, Muller C, Carling D, Kahn BB (2002) Leptin stimulates fatty-acid oxidation by activating AMP-activated protein kinase. Nature 415:339-343

Mogensen CE (1984) Microalbuminuria predicts clinical proteinuria and early mortality in maturity-onset diabetes. N Engl J Med 310:356-360

Moien-Afshari F, Ghosh S, Khazaei M, Kieffer TJ, Brownsey RW, Laher I (2008) Exercise restores endothelial function indepen- dently of weight loss or hyperglycaemic status in $\mathrm{db} / \mathrm{db}$ mice. Diabetologia 51:1327-1337

Montagnani M, Ravichandran LV, Chen H, Esposito DL, Quon MJ (2002) Insulin receptor substrate-1 and phosphoinositide-dependent kinase-1 are required for insulin-stimulated production of nitric oxide in endothelial cells. Mol Endocrinol 16:1931-1942

Moos MP, John N, Grabner R, Nossmann S, Gunther B, Vollandt R, Funk CD, Kaiser B, Habenicht AJ (2005) The lamina adventitia is the major site of immune cell accumulation in standard chowfed apolipoprotein E-deficient mice. Arterioscler Thromb Vasc Biol 25:2386-2391

Munzel T, Sinning C, Post F, Warnholtz A, Schulz E (2008) Pathophysiology, diagnosis and prognostic implications of endothelial dysfunction. Ann Med 40:180-196

Naka Y, Bucciarelli LG, Wendt T, Lee LK, Rong LL, Ramasamy R, Yan SF, Schmidt AM (2004) RAGE axis: animal models and novel insights into the vascular complications of diabetes. Arterioscler Thromb Vasc Biol 24:1342-1349

Nakagawa K, Higashi Y, Sasaki S, Oshima T, Matsuura H, Chayama K (2002) Leptin causes vasodilation in humans. Hypertens Res 25:161-165

Neel JV (1962) Diabetes mellitus: a "thrifty" genotype rendered detrimental by "progress"? Am J Hum Genet 14:353-362

Nguyen TT, Wang JJ, Islam FMA, Mitchell P, Tapp RJ, Zimmet PZ, Simpson R, Shaw J, Wong TY (2008) Retinal arteriolar narrowing predicts incidence of diabetes: the Australian diabetes, obesity and lifestyle (AusDiab) study. Diabetes 57:536-539

Nieuwdorp M, Mooij HL, Kroon J, Atasever B, Spaan JA, Ince C, Holleman F, Diamant M, Heine RJ, Hoekstra JB, Kastelein JJ, Stroes ES, Vink H (2006a) Endothelial glycocalyx damage coincides with microalbuminuria in type 1 diabetes. Diabetes 55:1127-1132

Nieuwdorp M, Haeften TW van, Gouverneur MC, Mooij HL, Lieshout MH van, Levi M, Meijers JC, Holleman F, Hoekstra JB, Vink H, Kastelein JJ, Stroes ES (2006b) Loss of endothelial glycocalyx during acute hyperglycemia coincides with endothelial dysfunction and coagulation activation in vivo. Diabetes $55: 480-486$

Noh H, King GL (2007) The role of protein kinase C activation in diabetic nephropathy. Kidney Int Suppl:S49-S53

Nosadini R, Velussi M, Brocco E, Abaterusso C, Piarulli F, Morgia G, Satta A, Faedda R, Abhyankar A, Luthman H, Tonolo G (2005) Altered transcapillary escape of albumin and microalbuminuria reflects two different pathogenetic mechanisms. Diabetes $54: 228-233$

Okado A, Kawasaki Y, Hasuike Y, Takahashi M, Teshima T, Fujii J, Taniguchi N (1996) Induction of apoptotic cell death by methylglyoxal and 3-deoxyglucosone in macrophage-derived cell lines. Biochem Biophys Res Commun 225:219-224

Okamoto E, Couse T, De Leon H, Vinten-Johansen J, Goodman RB, Scott NA, Wilcox JN (2001) Perivascular inflammation after balloon angioplasty of porcine coronary arteries. Circulation 104:2228-2235

Okon EB, Szado T, Laher I, McManus B, Breemen C van (2003) Augmented contractile response of vascular smooth muscle in a diabetic mouse model. J Vasc Res 40:520-530

Okon EB, Chung AWY, Rauniyar P, Padilla E, Tejerina T, McManus $\mathrm{BM}$, Luo H, Breemen C van (2005) Compromised arterial function in human type 2 diabetic patients. Diabetes 54:2415-2423

Okouchi M, Okayama N, Imai S, Omi H, Shimizu M, Fukutomi T, Itoh M (2002) High insulin enhances neutrophil transendothelial migration through increasing surface expression of platelet endothelial cell adhesion molecule-1 via activation of mitogen activated protein kinase. Diabetologia 45:1449-1456

Ouchi N, Kihara S, Arita Y, Maeda K, Kuriyama H, Okamoto Y, Hotta K, Nishida M, Takahashi M, Nakamura T, Yamashita S, Funahashi T, 
Matsuzawa Y (1999) Novel modulator for endothelial adhesion molecules: adipocyte-derived plasma protein adiponectin. Circulation 100:2473-2476

Ozcan U, Cao Q, Yilmaz E, Lee AH, Iwakoshi NN, Ozdelen E, Tuncman G, Gorgun C, Glimcher LH, Hotamisligil GS (2004) Endoplasmic reticulum stress links obesity, insulin action, and type 2 diabetes. Science 306:457-461

Ozcan U, Yilmaz E, Ozcan L, Furuhashi M, Vaillancourt E, Smith RO, Gorgun CZ, Hotamisligil GS (2006) Chemical chaperones reduce ER stress and restore glucose homeostasis in a mouse model of type 2 diabetes. Science 313:1137-1140

Pannirselvam M, Verma S, Anderson TJ, Triggle CR (2002) Cellular basis of endothelial dysfunction in small mesenteric arteries from spontaneously diabetic (db/db -/-) mice: role of decreased tetrahydrobiopterin bioavailability. Br J Pharmacol 136:255-263

Pardridge WM, Boado RJ, Farrell CR (1990) Brain-type glucose transporter (GLUT-1) is selectively localized to the blood-brain barrier. Studies with quantitative Western blotting and in situ hybridization. J Biol Chem 265:18035-18040

Patti ME, Virkamaki A, Landaker EJ, Kahn CR, Yki-Jarvinen H (1999) Activation of the hexosamine pathway by glucosamine in vivo induces insulin resistance of early postreceptor insulin signaling events in skeletal muscle. Diabetes 48:1562-1571

Perticone F, Ceravolo R, Candigliota M, Ventura G, Iacopino S, Sinopoli F, Mattioli PL (2001) Obesity and body fat distribution induce endothelial dysfunction by oxidative stress: protective effect of vitamin C. Diabetes 50:159-165

Picard F, Auwerx J (2002) PPAR(gamma) and glucose homeostasis. Annu Rev Nutr 22:167-197

Pieper GM, Siebeneich W, Moore-Hilton G, Roza AM (1997) Reversal by L-arginine of a dysfunctional arginine/nitric oxide pathway in the endothelium of the genetic diabetic BB rat. Diabetologia 40:910-915

Pilz S, Horejsi R, Moller R, Almer G, Scharnagl H, Stojakovic T, Dimitrova R, Weihrauch G, Borkenstein M, Maerz W, Schauenstein K, Mangge H (2005) Early atherosclerosis in obese juveniles is associated with low serum levels of adiponectin. J Clin Endocrinol Metab 90:4792-4796

Pober JS, Sessa WC (2007) Evolving functions of endothelial cells in inflammation. Nat Rev Immunol 7:803-815

Potenza MA, Marasciulo FL, Chieppa DM, Brigiani GS, Formoso G, Quon MJ, Montagnani M (2005) Insulin resistance in spontaneously hypertensive rats is associated with endothelial dysfunction characterized by imbalance between NO and ET-1 production. Am J Physiol Heart Circ Physiol 289:H813-H822

Quehenberger P, Exner M, Sunder-Plassmann R, Ruzicka K, Bieglmayer C, Endler G, Muellner C, Speiser W, Wagner O (2002) Leptin induces endothelin-1 in endothelial cells in vitro. Circ Res 90:711-718

Rahmouni K, Mark AL, Haynes WG, Sigmund CD (2004) Adipose depot-specific modulation of angiotensinogen gene expression in diet-induced obesity. Am J Physiol Endocrinol Metab 286:E891E895

Rahmouni K, Morgan DA, Morgan GM, Mark AL, Haynes WG (2005) Role of selective leptin resistance in diet-induced obesity hypertension. Diabetes 54:2012-2018

Raitakari M, Ilvonen T, Ahotupa M, Lehtimaki T, Harmoinen A, Suominen P, Elo J, Hartiala J, Raitakari OT (2004) Weight reduction with very-low-caloric diet and endothelial function in overweight adults: role of plasma glucose. Arterioscler Thromb Vasc Biol 24:124-128

Raman CS, Li H, Martasek P, Kral V, Masters BS, Poulos TL (1998) Crystal structure of constitutive endothelial nitric oxide synthase: a paradigm for pterin function involving a novel metal center. Cell 95:939-950
Rask-Madsen C, King GL (2007) Mechanisms of disease: endothelial dysfunction in insulin resistance and diabetes. Nat Clin Pract Endocrinol Metab 3:46-56

Ratcliffe PJ (2006) Understanding hypoxia signalling in cells - a new therapeutic opportunity? Clin Med 6:573-578

Reaven GM (1995) Pathophysiology of insulin resistance in human disease. Physiol Rev 75:473-486

Rehman J, Traktuev D, Li J, Merfeld-Clauss S, Temm-Grove CJ, Bovenkerk JE, Pell CL, Johnstone BH, Considine RV, March KL (2004) Secretion of angiogenic and antiapoptotic factors by human adipose stromal cells. Circulation 109:1292-1298

Rey FE, Li XC, Carretero OA, Garvin JL, Pagano PJ (2002) Perivascular superoxide anion contributes to impairment of endothelium-dependent relaxation: role of gp91(phox). Circulation 106:2497-2502

Ridker PM (2007) Inflammatory biomarkers and risks of myocardial infarction, stroke, diabetes, and total mortality: implications for longevity. Nutr Rev 65:S253-S259

Romero MJ, Platt DH, Tawfik HE, Labazi M, El Remessy AB, Bartoli M, Caldwell RB, Caldwell RW (2008) Diabetes-induced coronary vascular dysfunction involves increased arginase activity. Circ Res 102:95-102

Ross R (1999) Atherosclerosis - an inflammatory disease. N Engl J Med 340:115-126

Ross RM, Kolka CM, Rattigan S, Clark MG (2007) Acute blockade by endothelin-1 of haemodynamic insulin action in rats. Diabetologia 50:443-451

Roy S, Sala R, Cagliero E, Lorenzi M (1990) Overexpression of fibronectin induced by diabetes or high glucose: phenomenon with a memory. Proc Natl Acad Sci USA 87:404-408

Saraswathi V, Hasty AH (2006) The role of lipolysis in mediating the proinflammatory effects of very low density lipoproteins in mouse peritoneal macrophages. J Lipid Res 47:1406-1415

Sasaki S, Higashi Y, Nakagawa K, Kimura M, Noma K, Sasaki S, Hara K, Matsuura H, Goto C, Oshima T, Chayama K (2002) A low-calorie diet improves endothelium-dependent vasodilation in obese patients with essential hypertension. Am J Hypertens 15:302-309

Sasso FC, Torella D, Carbonara O, Ellison GM, Torella M, Scardone M, Marra C, Nasti R, Marfella R, Cozzolino D, Indolfi C, Cotrufo M, Torella R, Salvatore T (2005) Increased vascular endothelial growth factor expression but impaired vascular endothelial growth factor receptor signaling in the myocardium of type 2 diabetic patients with chronic coronary heart disease. J Am Coll Cardiol 46:827-834

Sayeski PP, Kudlow JE (1996) Glucose metabolism to glucosamine is necessary for glucose stimulation of transforming growth factoralpha gene transcription. J Biol Chem 271:15237-15243

Schalkwijk CG, Poland DC, Dijk W van, Kok A, Emeis JJ, Drager AM, Doni A, Hinsbergh VW van, Stehouwer CD (1999) Plasma concentration of C-reactive protein is increased in type I diabetic patients without clinical macroangiopathy and correlates with markers of endothelial dysfunction: evidence for chronic inflammation. Diabetologia 42:351-357

Schalkwijk CG, Bezu J van, Schors RC van der, Uchida K, Stehouwer CDA, Hinsbergh VWM van (2006) Heat-shock protein 27 is a major methylglyoxal-modified protein in endothelial cells. FEBS Lett 580:1565-1570

Schernthaner G, Morton JM (2008) Bariatric surgery in patients with morbid obesity and type 2 diabetes. Diabetes Care 31:S297-S302

Schmidt HH, Hofmann H, Schindler U, Shutenko ZS, Cunningham DD, Feelisch M (1996) No.NO from NO synthase. Proc Natl Acad Sci USA 93:14492-14497

Schnitzer JE, Oh P, Pinney E, Allard J (1994) Filipin-sensitive caveolae-mediated transport in endothelium: reduced transcytosis, scavenger endocytosis, and capillary permeability of select macromolecules. J Cell Biol 127:1217-1232 
Schoeller DA, Buchholz AC (2005) Energetics of obesity and weight control: does diet composition matter? J Am Diet Assoc 105:24-28

Schroeder CA Jr, Chen YL, Messina EJ (1999) Inhibition of NO synthesis or endothelium removal reveals a vasoconstrictor effect of insulin on isolated arterioles. Am J Physiol 276:815-820

Sciacqua A, Candigliota M, Ceravolo R, Scozzafava A, Sinopoli F, Corsonello A, Sesti G, Perticone F (2003) Weight loss in combination with physical activity improves endothelial dysfunction in human obesity. Diabetes Care 26:1673-1678

Seidell JC, Han TS, Feskens EJ, Lean ME (1997) Narrow hips and broad waist circumferences independently contribute to increased risk of non-insulin-dependent diabetes mellitus. J Intern Med 242:401-406

Seidell JC, Perusse L, Despres JP, Bouchard C (2001) Waist and hip circumferences have independent and opposite effects on cardiovascular disease risk factors: the Quebec Family Study. Am J Clin Nutr 74:315-321

SenBanerjee S, Lin Z, Atkins GB, Greif DM, Rao RM, Kumar A, Feinberg MW, Chen Z, Simon DI, Luscinskas FW, Michel TM, Gimbrone MA Jr, Garcia-Cardena G, Jain MK (2004) KLF2 is a novel transcriptional regulator of endothelial proinflammatory activation. J Exp Med 199:1305-1315

Serne EH, Stehouwer CD, Maaten JC ter, Wee PM ter, Rauwerda JA, Donker AJ, Gans RO (1999) Microvascular function relates to insulin sensitivity and blood pressure in normal subjects. Circulation 99:896-902

Serne EH, Jongh RT de, Eringa EC, IJzerman RG, Boer MP de, Stehouwer CD (2006) Microvascular dysfunction: causative role in the association between hypertension, insulin resistance and the metabolic syndrome? Essays Biochem 42:163-176

Sesti G, Federici IM, Hribal ML, Lauro D, Sbraccia P, Lauro R (2001) Defects of the insulin receptor substrate (IRS) system in human metabolic disorders. FASEB J 15:2099-2111

Shankar RR, Wu Y, Shen HQ, Zhu JS, Baron AD (2000) Mice with gene disruption of both endothelial and neuronal nitric oxide synthase exhibit insulin resistance. Diabetes 49:684-687

Shaul PW (1999) Regulation of vasodilator synthesis during lung development. Early Hum Dev 54:271-294

Shimokawa H, Yasutake H, Fujii K, Owada MK, Nakaike R, Fukumoto Y, Takayanagi T, Nagao T, Egashira K, Fujishima M, Takeshita A (1996) The importance of the hyperpolarizing mechanism increases as the vessel size decreases in endotheliumdependent relaxations in rat mesenteric circulation. J Cardiovasc Pharmacol 28:703-711

Shimomura I, Funahashi T, Takahashi M, Maeda K, Kotani K, Nakamura T, Yamashita S, Miura M, Fukuda Y, Takemura K, Tokunaga K, Matsuzawa Y (1996) Enhanced expression of PAI-1 in visceral fat: possible contributor to vascular disease in obesity. Nat Med 2:800-803

Shin HK, Kim YK, Kim KY, Lee JH, Hong KW (2004) Remnant lipoprotein particles induce apoptosis in endothelial cells by $\mathrm{NAD}(\mathrm{P}) \mathrm{H}$ oxidase-mediated production of superoxide and cytokines via lectin-like oxidized low-density lipoprotein receptor-1 activation: prevention by cilostazol. Circulation 109:10221028

Shinohara M, Thornalley PJ, Giardino I, Beisswenger P, Thorpe SR, Onorato J, Brownlee M (1998) Overexpression of glyoxalase-I in bovine endothelial cells inhibits intracellular advanced glycation endproduct formation and prevents hyperglycemia-induced increases in macromolecular endocytosis. J Clin Invest 101:1142-1147

Sierra-Honigmann MR, Nath AK, Murakami C, García-Cardeña G, Papapetropoulos A, Sessa WC, Madge LA, Schechner JS, Schwabb MB, Polverini PJ, Flores-Riveros JR (1998) Biological action of leptin as an angiogenic factor. Science 281:1683-1686
Simionescu M (2007) Implications of early structural-functional changes in the endothelium for vascular disease. Arterioscler Thromb Vasc Biol 27:266-274

Simionescu M, Gafencu A, Antohe F (2002) Transcytosis of plasma macromolecules in endothelial cells: a cell biological survey. Microsc Res Tech 57:269-288

Sjostrand M, Gudbjornsdottir S, Holmang A, Lonn L, Strindberg L, Lonnroth P (2002) Delayed transcapillary transport of insulin to muscle interstitial fluid in obese subjects. Diabetes 51:2742-2748

Soltis EE, Cassis LA (1991) Influence of perivascular adipose tissue on rat aortic smooth muscle responsiveness. Clin Exp Hypertens [A] 13:277-296

Stehouwer CD, Smulders YM (2006) Microalbuminuria and risk for cardiovascular disease: analysis of potential mechanisms. J Am Soc Nephrol 17:2106-2111

Stehouwer CD, Stroes ES, Hackeng WH, Mulder PG, Den Ottolander GJ (1991) von Willebrand factor and development of diabetic nephropathy in IDDM. Diabetes 40:971-976

Stehouwer CD, Lambert J, Donker AJ, Hinsbergh VW van (1997) Endothelial dysfunction and pathogenesis of diabetic angiopathy. Cardiovasc Res 34:55-68

Stehouwer CD, Gall MA, Twisk JW, Knudsen E, Emeis JJ, Parving HH (2002) Increased urinary albumin excretion, endothelial dysfunction, and chronic low-grade inflammation in type 2 diabetes: progressive, interrelated, and independently associated with risk of death. Diabetes 51:1157-1165

Stehouwer CD, Henry RM, Dekker JM, Nijpels G, Heine RJ, Bouter LM (2004) Microalbuminuria is associated with impaired brachial artery, flow-mediated vasodilation in elderly individuals without and with diabetes: further evidence for a link between microalbuminuria and endothelial dysfunction-the Hoorn study. Kidney Int Suppl:S42-S44

Stratton IM, Adler AI, Neil HA, Matthews DR, Manley SE, Cull CA, Hadden D, Turner RC, Holman RR (2000) Association of glycaemia with macrovascular and microvascular complications of type 2 diabetes (UKPDS 35): prospective observational study. BMJ 321:405-412

Tamarat R, Silvestre JS, Huijberts M, Benessiano J, Ebrahimian TG, Duriez M, Wautier MP, Wautier JL, Levy BI (2003) Blockade of advanced glycation end-product formation restores ischemia-induced angiogenesis in diabetic mice. Proc Natl Acad Sci USA 100:8555-8560

Taniguchi CM, Emanuelli B, Kahn CR (2006) Critical nodes in signalling pathways: insights into insulin action. Nat Rev Mol Cell Biol 7:85-96

Tesfamariam B, DeFelice AF (2007) Endothelial injury in the initiation and progression of vascular disorders. Vascul Pharmacol 46:229-237

The Action to Control Cardiovascular Risk in Diabetes Study Group (2008) Effects of intensive glucose lowering in type 2 diabetes. $\mathrm{N}$ Engl J Med 358:2545-2559

The ADVANCE Collaborative Group (2008) Intensive blood glucose control and vascular outcomes in patients with type 2 diabetes. $\mathrm{N}$ Engl J Med 358:2560-2572

The Diabetes Control and Complications Trial Research Group (1993) The effect of intensive treatment of diabetes on the development and progression of long-term complications in insulin-dependent diabetes mellitus. N Engl J Med 329:977-986

Thornalley PJ (1990) The glyoxalase system: new developments towards functional characterization of a metabolic pathway fundamental to biological life. Biochem J 269:1-11

Tonelli J, Li W, Kishore P, Pajvani UB, Kwon E, Weaver C, Scherer PE, Hawkins M (2004) Mechanisms of early insulinsensitizing effects of thiazolidinediones in type 2 diabetes. Diabetes 53:1621-1629

Trayhurn P, Wood IS (2004) Adipokines: inflammation and the pleiotropic role of white adipose tissue. Br J Nutr 92:347-355 
Tsuda K, Nishio I (2004) Leptin and nitric oxide production in normotensive and hypertensive men. Obes Res 12:1223-1237

United Kingdom Prospective Diabetes Study (UKPDS) (1995) 13: Relative efficacy of randomly allocated diet, sulphonylurea, insulin, or metformin in patients with newly diagnosed non-insulin dependent diabetes followed for three years. BMJ 310:83-88

Vecchione C, Aretini A, Maffei A, Marino G, Selvetella G, Poulet R, Trimarco V, Frati G, Lembo G (2003) Cooperation between insulin and leptin in the modulation of vascular tone. Hypertension 42:166-170

Verlohren S, Dubrovska G, Tsang SY, Essin K, Luft FC, Huang Y, Gollasch M (2004) Visceral periadventitial adipose tissue regulates arterial tone of mesenteric arteries. Hypertension 44:271-276

Vicent D, Ilany J, Kondo T, Naruse K, Fisher SJ, Kisanuki YY, Bursell S, Yanagisawa M, King GL, Kahn CR (2003) The role of endothelial insulin signaling in the regulation of vascular tone and insulin resistance. J Clin Invest 111:1373-1380

Vincent MA, Barrett EJ, Lindner JR, Clark MG, Rattigan S (2003) Inhibiting NOS blocks microvascular recruitment and blunts muscle glucose uptake in response to insulin. Am J Physiol Endocrinol Metab 285:E123-E129

Vora DK, Fang ZT, Liva SM, Tyner TR, Parhami F, Watson AD, Drake TA, Territo MC, Berliner JA (1997) Induction of Pselectin by oxidized lipoproteins. Separate effects on synthesis and surface expression. Circ Res 80:810-818

Vosseller K, Wells L, Lane MD, Hart GW (2002) Elevated nucleocytoplasmic glycosylation by O-GlcNAc results in insulin resistance associated with defects in Akt activation in 3T3-L1 adipocytes. Proc Natl Acad Sci 99:5313-5318

Wautier MP, Chappey O, Corda S, Stern DM, Schmidt AM, Wautier JL (2001) Activation of NADPH oxidase by AGE links oxidant stress to altered gene expression via RAGE. Am J Physiol Endocrinol Metab 280:E685-E694

Weir MR (2007) Microalbuminuria and cardiovascular disease. Clin J Am Soc Nephrol 2:581-590

Weisberg SP, McCann D, Desai M, Rosenbaum M, Leibel RL, Ferrante AW Jr (2003) Obesity is associated with macrophage accumulation in adipose tissue. J Clin Invest 112:1796-1808

Wellen KE, Hotamisligil GS (2003) Obesity-induced inflammatory changes in adipose tissue. J Clin Invest 112:1785-1788

Wever RM, Dam T van, Rijn HJ van, Groot F de, Rabelink TJ (1997) Tetrahydrobiopterin regulates superoxide and nitric oxide generation by recombinant endothelial nitric oxide synthase. Biochem Biophys Res Commun 237:340-344

Wiernsperger N (1994) Vascular defects in the aetiology of peripheral insulin resistance in diabetes. A critical review of hypotheses and facts. Diabetes Metab Rev 10:287-307

Wild S, Roglic G, Green A, Sicree R, King H (2004) Global prevalence of diabetes: estimates for the year 2000 and projections for 2030. Diabetes Care 27:1047-1053

Williams B, Baker AQ, Gallacher B, Lodwick D (1995) Angiotensin II increases vascular permeability factor gene expression by human vascular smooth muscle cells. Hypertension 25:913-917

Williams IL, Wheatcroft SB, Shah AM, Kearney MT (2002) Obesity, atherosclerosis and the vascular endothelium: mechanisms of reduced nitric oxide bioavailability in obese humans. Int $\mathrm{J}$ Obes Relat Metab Disord 26:754-764

Williams IL, Chowienczyk PJ, Wheatcroft SB, Patel AG, Sherwood RA, Momin A, Shah AM, Kearney MT (2005) Endothelial function and weight loss in obese humans. Obes Surg 15:1055-1060

Williamson JR, Chang K, Frangos M, Hasan KS, Ido Y, Kawamura T, Nyengaard JR, van den EM, Kilo C, Tilton RG (1993) Hyperglycemic pseudohypoxia and diabetic complications. Diabetes $42: 801-813$
Winters B, Mo Z, Brooks-Asplund E, Kim S, Shoukas A, Li D, Nyhan D, Berkowitz DE (2000) Reduction of obesity, as induced by leptin, reverses endothelial dysfunction in obese (Lepob) mice. J Appl Physiol 89:2382-2390

Wolf G, Chen S, Ziyadeh FN (2005) From the periphery of the glomerular capillary wall toward the center of disease: podocyte injury comes of age in diabetic nephropathy. Diabetes 54:1626-1634

Wolinsky H (1980) A proposal linking clearance of circulating lipoproteins to tissue metabolic activity as a basis for understanding atherogenesis. Circ Res 47:301-311

Woo KS, Chook P, Yu CW, Sung RYT, Qiao M, Leung SSF, Lam CWK, Metreweli C, Celermajer DS (2004) Effects of diet and exercise on obesity-related vascular dysfunction in children. Circulation 109:1981-1986

Xu H, Barnes GT, Yang Q, Tan G, Yang D, Chou CJ, Sole J, Nichols A, Ross JS, Tartaglia LA, Chen H (2003) Chronic inflammation in fat plays a crucial role in the development of obesity-related insulin resistance. J Clin Invest 112:1821-1830

Xue X, Piao JH, Nakajima A, Sakon-Komazawa S, Kojima Y, Mori K, Yagita H, Okumura K, Harding H, Nakano H (2005) Tumor necrosis factor alpha [TNF(alpha)] induces the unfolded protein response (UPR) in a reactive oxygen species (ROS)dependent fashion, and the UPR counteracts ROS accumulation by TNF(alpha). J Biol Chem 280:33917-33925

Yan SD, Schmidt AM, Anderson GM, Zhang J, Brett J, Zou YS, Pinsky D, Stern D (1994) Enhanced cellular oxidant stress by the interaction of advanced glycation end products with their receptors/binding proteins. J Biol Chem 269:9889-9897

Yan SF, Ramasamy R, Schmidt AM (2008) Mechanisms of disease: advanced glycation end-products and their receptor in inflammation and diabetes complications. Nat Clin Pract Endocrinol Metab 4:285-293

Yang YJ, Hope ID, Ader M, Bergman RN (1994) Importance of transcapillary insulin transport to dynamics of insulin action after intravenous glucose. Am J Physiol 266:E17-E25

Yao D, Taguchi T, Matsumura T, Pestell R, Edelstein D, Giardino I, Suske G, Rabbani N, Thornalley PJ, Sarthy VP, Hammes HP, Brownlee M (2007) High glucose increases angiopoietin-2 transcription in microvascular endothelial cells through methylglyoxal modification of mSin3A. J Biol Chem 282:31038-31045

Yasuda S, Miyazaki S, Kanda M, Goto Y, Suzuki M, Harano Y, Nonogi $H$ (2006) Intensive treatment of risk factors in patients with type-2 diabetes mellitus is associated with improvement of endothelial function coupled with a reduction in the levels of plasma asymmetric dimethylarginine and endogenous inhibitor of nitric oxide synthase. Eur Heart J 27:1159-1165

Youd JM, Rattigan S, Clark MG (2000) Acute impairment of insulinmediated capillary recruitment and glucose uptake in rat skeletal muscle in vivo by TNF-alpha. Diabetes 49:1904-1909

Yuan SY, Breslin JW, Perrin R, Gaudreault N, Guo M, Kargozaran H, Wu MH (2007) Microvascular permeability in diabetes and insulin resistance. Microcirculation 14:363-373

Yudkin JS, Stehouwer CD, Emeis JJ, Coppack SW (1999) C-reactive protein in healthy subjects: associations with obesity, insulin resistance, and endothelial dysfunction: a potential role for cytokines originating from adipose tissue? Arterioscler Thromb Vasc Biol 19:972-978

Zeeuw D de, Parving HH, Henning RH (2006) Microalbuminuria as an early marker for cardiovascular disease. J Am Soc Nephrol 17:2100-2105

Zhang K, Kaufman RJ (2008) From endoplasmic-reticulum stress to the inflammatory response. Nature 454:455-462

Zhang L, Newman JMB, Richards SM, Rattigan S, Clark MG (2005) Microvascular flow routes in muscle controlled by vasoconstrictors. Microvasc Res 70:7-16 